\title{
Functional characteristics of neonatal rat $\beta$ cells with distinct markers
}

\author{
G A Martens ${ }^{1,2}$, E Motté', G Kramer ${ }^{3}$, G Stangé', L W Gaarn ${ }^{4}$, K Hellemans ${ }^{1}$, J H Nielsen ${ }^{4}$, \\ J M Aerts ${ }^{3}$, Z Ling' ${ }^{1}$ and $D$ Pipeleers ${ }^{1}$ \\ 'Diabetes Research Center, Brussels Free University (VUB), Laarbeeklaan 103, B1090 Brussel, Belgium \\ ${ }^{2}$ Department of Clinical Chemistry and Radioimmunology, Universitair Ziekenhuis Brussel, Laarbeeklaan 101, \\ B1090 Brussels, Belgium \\ ${ }^{3}$ Department of Medical Biochemistry, Academisch Medisch Centrum, Amsterdam, The Netherlands \\ ${ }^{4}$ Department of Biomedical Sciences, University of Copenhagen, Copenhagen, Denmark
}

Correspondence should be addressed to G A Martens

Email

geert.martens@vub.ac.be

\begin{abstract}
Neonatal $\beta$ cells are considered developmentally immature and hence less glucose responsive. To study the acquisition of mature glucose responsiveness, we compared glucose-regulated redox state, insulin synthesis, and secretion of $\beta$ cells purified from neonatal or 10-week-old rats with their transcriptomes and proteomes measured by oligonucleotide and LC-MS/MS profiling. Lower glucose responsiveness of neonatal $\beta$ cells was explained by two distinct properties: higher activity at low glucose and lower activity at high glucose. Basal hyperactivity was associated with higher $N A D(P) H$, a higher fraction of neonatal $\beta$ cells actively incorporating ${ }^{3} \mathrm{H}$-tyrosine, and persistently increased insulin secretion below $5 \mathrm{mM}$ glucose. Neonatal $\beta$ cells lacked the steep glucose-responsive NAD(P)H rise between 5 and $10 \mathrm{mM}$ glucose characteristic for adult $\beta$ cells and accumulated less $\mathrm{NAD}(\mathrm{P}) \mathrm{H}$ at high glucose. They had twofold lower expression of malate/aspartate-NADH shuttle and most glycolytic enzymes. Genome-wide profiling situated neonatal $\beta$ cells at a developmental crossroad: they showed advanced endocrine differentiation when specifically analyzed for their mRNA/protein level of classical neuroendocrine markers. On the other hand, discrete neonatal $\beta$ cell subpopulations still expressed mRNAs/proteins typical for developing/proliferating tissues. One example, delta-like 1 homolog (DLK1) was used to investigate whether neonatal $\beta$ cells with basal hyperactivity corresponded to a more immature subset with high DLK1, but no association was found. In conclusion, the current study supports the importance of glycolytic NADH-shuttling in stimulus function coupling, presents basal hyperactivity as novel property of neonatal $\beta$ cells, and provides potential markers to recognize intercellular developmental differences in the endocrine pancreas.
\end{abstract}
Key Words
- islet cells
- microarray
neonatal
- pancreatic $\beta$ cell
- gene expression

\section{Introduction}

Therapeutic control of $\beta$ cell proliferation is considered an important route toward cure in diabetes. The interest in the underlying mechanisms and signals that control $\beta$ cell proliferation has revived the interest in the physiological conditions characterized by activated $\beta$ cell growth and/or proliferation. Examples include the physiological $\beta$ cell mass expansion during pregnancy, in adaptation to obesity and during growth. Here, we studied the $\beta$ cell in
Journal of Molecular Endocrinology (2014) 52, 11-28 
the neonatal pancreas ( $2-3$ days after birth): during the first months of postnatal rat life, the total $\beta$ cell number expands more than tenfold mainly due to $\beta$ cell division (Hellmann 1959, Hellman et al. 1961, McEvoy 1981, Kaung 1994). Fetal and neonatal $\beta$ cells have also been reported to have a lower glucose-stimulated insulin secretion (GSIS) than adult $\beta$ cells (Asplund et al. 1969, Grill et al. 1981, Hellerstrom \& Swenne 1991). Both their higher propensity to proliferate and their lower functional glucose responsiveness are generally considered as two sides of a same coin: both properties are assumed to reflect an incompletely differentiated $\beta$ cell phenotype that has, on the one hand, not yet assumed full expression of all genes that are quintessential for the specialized glucose-sensing function of a mature $\beta$ cell (Rorsman et al. 1989, Tan et al. 2002, Jermendy et al. 2011) and, on the other hand, likely maintains expression of protein markers typically encountered in developing tissues. There are, to date, relatively few independently confirmed gene or protein markers that can discern mature from immature $\beta$ cells. One solidly validated marker of postnatal $\beta$ cell maturation is the switch from $\mathrm{v}$-maf musculoaponeurotic fibrosarcoma oncogene homolog B (MAFB) to MAFA (Nishimura et al. 2006, Artner et al. 2007, 2010). Other proposed markers require further investigation (Aye et al. 2010). In this study, we sought to identify novel protein markers for $\beta$ cell maturation and acquisition of glucose responsiveness, by comparing the mRNA and protein expression blueprint and glucose-regulated insulin synthesis and secretion of neonatal (postnatal days 2-3) and adult (10 weeks old) rat $\beta$ cells. More specifically, our aim was dual: i) identify positive markers of differentiation by studying the postnatal appearance of the gene expression pattern characteristic for mature, fully differentiated $\beta$ cells and ii) investigate possible markers for the presumed residual developmental immaturity in the neonatal stage, and see whether their expression correlates with the typical functional properties of the neonatal $\beta$ cells. We describe a FACS-based method to isolate a representative population of $\beta$ cells from rat pancreas at postnatal days 2-3. Their gene expression and in vitro function was compared with those of 10-week-old adult $\beta$ cells, serving as reference. As anticipated, neonatal $\beta$ cells displayed a lower glucose-inducible insulin synthesis, but surprisingly, this was not only explained by a blunted response to high glucose stimulation but also explained by basal hyperactivity at low glucose concentrations. This led to further investigation into the differential gene expression between neonatal and 10-week-old FACSsorted rat $\beta$ cell preparations to get a global view on endocrine differentiation in neonatal $\beta$ cells and to select a possible protein marker for residual developmental immaturity at this stage.

\section{Materials and methods}

\section{$\beta$ cell isolation and culture}

Adult (10 weeks) male Wistar rats (150-250 g, Janvier, Le Genest Saint Isle, France) were bred according to Belgian regulations of animal welfare and used in experiments that were approved by the Local Ethics Committee. Use of these animal cells and tissues was approved by the Commissie Proefdiergebruik (CPG, VUB for a project entitled 'in vitro and in vivo markers for $\beta$ cell death and function', approval ID 07-274-3). Ten-week-old (adult) $\beta$ cells were FACS purified as described in Van De Winkel \& Pipeleers (1983). Neonatal $\beta$ cells were isolated from male and female rats at postnatal days $2-3$ as follows (Fig. 1): i) neonatal endocrine aggregate-enriched preparations were collected by gradient centrifugation rather than handpicking of islets in 10-week-old rats: collagenase-digested pancreas was density centrifuged first over a Ficoll layer $(1.10 \mathrm{~g} / \mathrm{ml})$ to separate exocrine from endocrine cells; the endocrineenriched interphase was collected and ii) trypsinized to single cells, additionally purified over a Percoll $(1.04 \mathrm{~g} / \mathrm{ml})$ layer to separate viable from damaged cells prior to FACS sorting. The 10-week-old $\beta$ cells are mainly discriminated from other islet cell types by their higher cell size (forward scatter (FSC)) in combination with higher FAD/FMN fluorescence (Fig. 1C; Van De Winkel \& Pipeleers 1983). As their flavin fluorescence is lower in neonatal $\beta$ cell, a combination of FSC and cellular complexity/granulation (side scatter (SSC)) is used to separate neonatal $\beta$ cells from a less granulated cell population; the latter SSC ${ }^{\text {LOW }}$ population contains not only exocrine duct cells but also endothelial and mesenchymal cells and a very small fraction of insulin-positive cells.

\section{In vitro experiments}

Rat $\beta$ cells were cultured in Ham's F10 nutrient mixture (Gibco, Invitrogen Corporation) supplemented with 0.5\% BSA (Cohn Analog, Sigma), $2 \mathrm{mM}$ glutamine, penicillin $(100 \mathrm{U} / \mathrm{ml})$, and streptomycin $(0.1 \mathrm{mg} / \mathrm{ml})$ at the indicated glucose concentrations. Protein biosynthetic rates were measured by ${ }^{3} \mathrm{H}$-Tyr incorporation, in batch analysis, or in single cells on slides by autoradiography as described previously (Kiekens et al. 1992). Analysis of metabolic redox state $(\mathrm{NAD}(\mathrm{P}) \mathrm{H}, \mathrm{FAD} / \mathrm{FMN})$ was done as described

Published by Bioscientifica Ltd. 


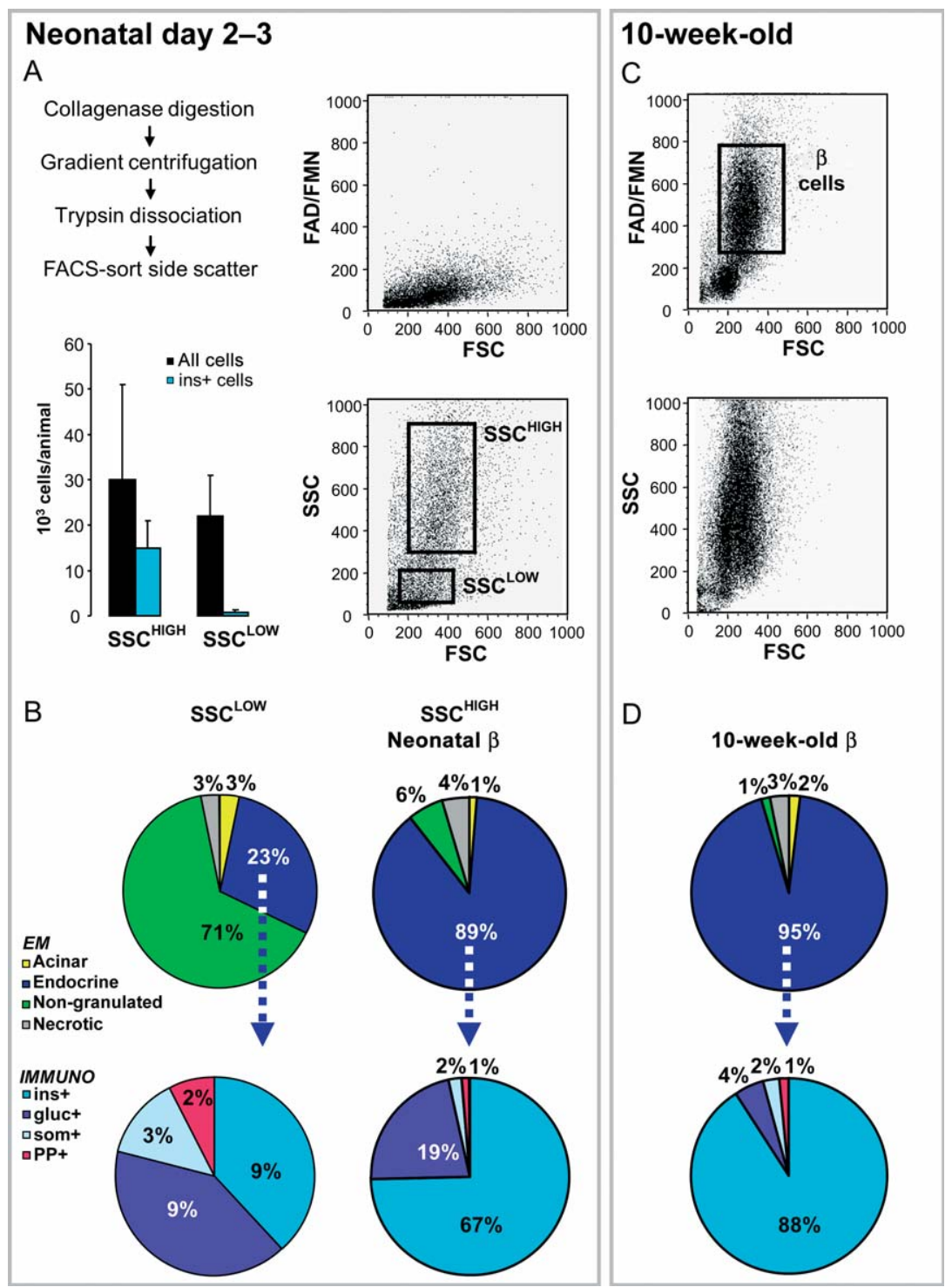

\section{Figure 1}

Isolation and cellular composition of neonatal and 10-week-old $\beta$ cell preparations. (A) FACS isolation of neonatal rat $\beta$ cells (A and B) in comparison to the standardized FACS purification of 10-week-old rat $\beta$ cells (C and D). Dot plots in (A and C) show FACS-sorting parameters to obtain the respective cell fractions. Ten-week-old $\beta$ cells are purified from handpicked islets by their high forward scatter (FSC) and endogenous flavin adenine di-(FAD) or mono-(FMN) nucleotide autofluorescence (C). $\beta$ cells from day $2-3$ neonatal pancreas are FACS enriched from gradientenriched endocrine aggregates based on their FSC and side scatter (SSC).

(Martens et al. 2005, 2006). All chemicals were obtained from Sigma unless otherwise stated.

\section{Gene chip hybridization and data analysis}

One to three micrograms of RNA were extracted from three independent biological replicates, each consisting
The $\mathrm{SSC}^{\mathrm{HIGH}}$ fraction contains $>90 \%$ of isolated neonatal insulin-positive cells (blue bars in inset (A)) and is further referred to as 'neonatal $\beta$ cells'. (B) Cellular composition by electron (EM) and immunofluorescence (IMMUNO) microscopy of SSC ${ }^{\mathrm{HIGH}}$ and $\mathrm{SSC}^{\mathrm{LOW}}$ populations: the $\mathrm{SSC}^{\mathrm{HIGH}}$ neonatal $\beta$ cell population has overall endocrine purity of $89 \%$, slightly $<10$-week-old $\beta$ cells $(95 \%$, D). Endocrine composition with percent insulin- (ins + ), glucagon- (gluc + ), somatostatin (som + ), and pancreatic polypeptide $(\mathrm{PP}+)$ cells is shown in pie graphs below. Data represent mean values of 15 independent isolations.

of a $\beta$ cell pool obtained from ten 10-week-old or 50 neonatal rats, and cRNA hybridized to Affymetrix (Santa Clara, CA, USA) RG230.20 arrays as described previously (Martens et al. 2011). Raw data and MIAME are shared at Gene Expression Omnibus as data set GSE47174. Gene chip data analysis: scanned arrays were analyzed with dChip model-based expression analysis (Li \& Wong

Published by Bioscientifica Ltd. 
Table 1 Quantitative LC-MS/MS proteomics of neonatal and 10-week-old $\beta$ cells. Total cellular protein was extracted from freshly isolated neonatal $(n=4)$ and 10-week-old $(n=3) \beta$ cells, trypsinized, and analyzed by one-dimensional liquid chromatography alternate-scanning mass spectrometry. This allows precise relative quantification of the molar abundances of identified protein within one cell preparation. These relative molar abundances were then expressed as fold change of the corresponding cyclophilin A/peptidylprolyl isomerase A (PPIA) abundance of that same preparation as reference, to allow normalization across different cell types and isolations. Data indicate average \pm s.D. of target/PPIA relative molar amounts of the selected proteins

\begin{tabular}{|c|c|c|c|c|c|}
\hline \multirow[b]{2}{*}{ Gene } & \multirow[b]{2}{*}{ Protein description } & \multirow[b]{2}{*}{ Uniprot } & Neonatal $\beta$ & 10 -week rat $\beta$ & \multirow[b]{2}{*}{$\boldsymbol{P}$} \\
\hline & & & $\begin{array}{l}\text { Relative molar amount } \\
\quad \text { (average } \pm \text { s.D.) }\end{array}$ & $\begin{array}{c}\text { Target/PPIA } \\
\text { (average } \pm \text { s.D.) }\end{array}$ & \\
\hline \multicolumn{6}{|c|}{ Glycolysis } \\
\hline Gpi & Glucose 6 phosphate isomerase & Q6P6V0 & & $0.129 \pm 0.002$ & \\
\hline Aldoa & Fructose-bisphosphate aldolase $A$ & P05065 & $0.116 \pm 0.003$ & $0.264 \pm 0.010$ & 0.001 \\
\hline Tpil & Triosephosphate isomerase & P48500 & $0.273 \pm 0.096$ & $0.385 \pm 0.095$ & 0.191 \\
\hline Gapdh & $\begin{array}{l}\text { Glyceraldehyde-3-phosphate } \\
\text { dehydrogenase }\end{array}$ & P04797 & $0.927 \pm 0.261$ & $1.285 \pm 0.161$ & 0.076 \\
\hline Pgk1 & Phosphoglycerate kinase 1 & P16617 & & $0.211 \pm 0.050$ & \\
\hline Pgam1 & Phosphoglycerate mutase 1 & P25113 & $0.230 \pm 0.018$ & $0.586 \pm 0.093$ & 0.020 \\
\hline Eno1 & Alpha-enolase & P04764 & $0.510 \pm 0.088$ & $1.056 \pm 0.143$ & 0.009 \\
\hline Eno2 & Gamma-enolase & P07323 & $0.033 \pm 0.026$ & $0.217 \pm 0.058$ & 0.019 \\
\hline Eno3 & Beta-enolase & P15429 & $0.032 \pm 0.004$ & $0.032 \pm 0.011$ & 0.949 \\
\hline$P k / r$ & Pyruvate kinase isozymes $\mathrm{R} / \mathrm{L}$ & P12928 & $0.032 \pm 0.025$ & $0.088 \pm 0.031$ & 0.063 \\
\hline$P k m$ & Pyruvate kinase isozymes $\mathrm{M} 1 / \mathrm{M} 2$ & P11980 & $1.202 \pm 0.269$ & $1.609 \pm 0.045$ & 0.054 \\
\hline \multicolumn{6}{|c|}{$\begin{array}{l}\text { Malate-aspartate } \\
\text { NADH shuttle }\end{array}$} \\
\hline$M d h 1$ & $\begin{array}{l}\text { Malate dehydrogenase } \\
\text { cytoplasmic }\end{array}$ & O88989 & $0.523 \pm 0.095$ & $2.219 \pm 0.052$ & 0.000 \\
\hline Got1 & $\begin{array}{l}\text { Aspartate aminotransferase } \\
\text { cytoplasmic }\end{array}$ & P13221 & & $0.086 \pm 0.009$ & \\
\hline Mdh2 & $\begin{array}{l}\text { Malate dehydrogenase, } \\
\text { mitochondrial }\end{array}$ & P04636 & $0.547 \pm 0.136$ & $0.531 \pm 0.178$ & 0.907 \\
\hline Got2 & $\begin{array}{l}\text { Aspartate aminotransferase, } \\
\text { mitochondrial }\end{array}$ & P00507 & $0.154 \pm 0.005$ & $0.231 \pm 0.132$ & 0.420 \\
\hline \multicolumn{6}{|c|}{ 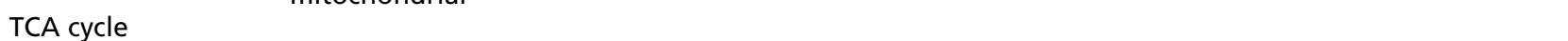 } \\
\hline Aco2 & $\begin{array}{l}\text { Aconitate hydratase, } \\
\text { mitochondrial }\end{array}$ & Q9ER34 & $0.360 \pm 0.088$ & $0.346 \pm 0.162$ & 0.906 \\
\hline Acly & ATP-citrate synthase & P16638 & $0.405 \pm 0.118$ & $0.695 \pm 0.057$ & 0.010 \\
\hline \multicolumn{6}{|c|}{ Mitochondrial } \\
\hline Atp5a1 & ATP synthase subunit alpha & P15999 & $0.750 \pm 0.211$ & $0.839 \pm 0.064$ & 0.486 \\
\hline Atp $5 b$ & ATP synthase subunit beta & P10719 & $0.699 \pm 0.165$ & $0.885 \pm 0.108$ & 0.191 \\
\hline Atp5h & ATP synthase subunit d & P31399 & $0.149 \pm 0.061$ & $0.174 \pm 0.047$ & 0.691 \\
\hline \multicolumn{6}{|c|}{$\beta$-oxidation } \\
\hline Etfa & $\begin{array}{l}\text { Electron transfer flavoprotein } \\
\text { subunit alpha }\end{array}$ & P13803 & $0.124 \pm 0.059$ & $0.086 \pm 0.041$ & 0.527 \\
\hline Hadha & $\begin{array}{l}\text { Trifunctional enzyme subunit } \\
\text { alpha }\end{array}$ & Q64428 & $0.184 \pm 0.136$ & $0.173 \pm 0.022$ & 0.926 \\
\hline Acaa2 & 3-Ketoacyl-CoA thiolase & P13437 & $0.087 \pm 0.014$ & $0.083 \pm 0.021$ & 0.846 \\
\hline Hadh & $\begin{array}{l}\text { Hydroxyacyl coenzyme A } \\
\text { dehydrogenase }\end{array}$ & Q9WVK & $0.401 \pm 0.082$ & $1.010 \pm 0.380$ & 0.104 \\
\hline Echdc1 & $\begin{array}{l}\text { Enoyl CoA hydratase domain } \\
\text { containing protein } 1\end{array}$ & Q6AYG5 & & $0.123 \pm 0.032$ & \\
\hline \multicolumn{6}{|c|}{ Protein synthesis } \\
\hline Eef2 & Elongation factor 2 & P05197 & $0.298 \pm 0.063$ & $0.360 \pm 0.023$ & 0.146 \\
\hline Eef1a1 & Elongation factor 1 -alpha 1 & P62630 & $1.327 \pm 0.052$ & $1.826 \pm 0.357$ & 0.134 \\
\hline Pdia3 & Protein disulfide-isomerase $\mathrm{A} 3$ & P11598 & $1.194 \pm 0.337$ & $1.111 \pm 0.150$ & 0.680 \\
\hline Pdia6 & Protein disulfide-isomerase $\mathrm{A} 6$ & Q63081 & $1.154 \pm 0.267$ & $0.987 \pm 0.165$ & 0.357 \\
\hline Uch/1 & $\begin{array}{l}\text { Ubiquitin carboxyl-terminal } \\
\text { hydrolase isozyme L1 }\end{array}$ & Q00981 & $0.267 \pm 0.028$ & $0.396 \pm 0.010$ & 0.074 \\
\hline
\end{tabular}

http://jme.endocrinology-journals.org DOI: 10.1530/JME-13-0106 (c) 2014 Society for Endocrinology Printed in Great Britain 
Table 1 Continued

\begin{tabular}{|c|c|c|c|c|c|}
\hline \multirow[b]{2}{*}{ Gene } & \multirow[b]{2}{*}{ Protein description } & \multirow[b]{2}{*}{ Uniprot } & Neonatal $\beta$ & 10-week rat $\beta$ & \multirow[b]{2}{*}{$\boldsymbol{P}$} \\
\hline & & & $\begin{array}{l}\text { Relative molar amount } \\
\quad \text { (average } \pm \text { s.D.) }\end{array}$ & $\begin{array}{c}\text { Target/PPIA } \\
\text { (average } \pm \text { s.D.) }\end{array}$ & \\
\hline \multicolumn{6}{|c|}{ Vesicle secretion } \\
\hline Arhgdia & Rho GDP-dissociation inhibitor 1 & Q5XI73 & $0.464 \pm 0.195$ & $0.233 \pm 0.007$ & 0.098 \\
\hline Gdi1 & $\begin{array}{l}\text { Rab GDP-dissociation inhibitor } \\
\text { alpha }\end{array}$ & P50398 & $0.255 \pm 0.068$ & $0.340 \pm 0.050$ & 0.113 \\
\hline Gnai2 & $\begin{array}{l}\text { Guanine nucleotide-binding } \\
\text { protein } \mathrm{G}(\mathrm{i}) \text { subunit alpha-2 }\end{array}$ & P04897 & $0.191 \pm 0.081$ & $0.101 \pm 0.005$ & 0.193 \\
\hline \multicolumn{6}{|c|}{ Secretory proteins } \\
\hline Chga & Chromogranin-A & P10354 & $0.426 \pm 0.107$ & $0.202 \pm 0.063$ & 0.047 \\
\hline $\operatorname{Scg} 2$ & Secretogranin-2 & P10362 & $0.414 \pm 0.172$ & $0.245 \pm 0.004$ & 0.143 \\
\hline $\operatorname{Scg} 3$ & Secretogranin-3 & P47868 & $0.374 \pm 0.060$ & $0.090 \pm 0.035$ & 0.001 \\
\hline $\operatorname{Scg} 5$ & Neuroendocrine protein 7B2 & P27682 & $0.446 \pm 0.086$ & $0.190 \pm 0.001$ & 0.010 \\
\hline Scgn & Secretagogin & Q6R556 & $0.290 \pm 0.016$ & $0.356 \pm 0.030$ & 0.042 \\
\hline Basp1 & Brain acid soluble protein 1 & Q05175 & $0.155 \pm 0.036$ & $0.044 \pm 0.020$ & 0.004 \\
\hline Pcsk1n & $\begin{array}{l}\text { Proprotein convertase subtilisin/ } \\
\text { kexin type } 1 \text { inhibitor }\end{array}$ & Q9QXU9 & $0.518 \pm 0.186$ & $0.177 \pm 0.021$ & 0.034 \\
\hline Pcsk1 & Neuroendocrine convertase 1 & P28840 & $0.176 \pm 0.055$ & $0.164 \pm 0.035$ & 0.770 \\
\hline Cpe & Carboxypeptidase E & P15087 & $0.822 \pm 0.093$ & $0.541 \pm 0.074$ & 0.007 \\
\hline \multicolumn{6}{|c|}{ Miscellaneous } \\
\hline Ubc & Ubiquitin C & Q63429 & $4.916 \pm 1.244$ & $1.529 \pm 0.216$ & 0.011 \\
\hline Actb & Actin, cytoplasmic 1 & P60711 & $6.163 \pm 2.374$ & $2.409 \pm 0.067$ & 0.051 \\
\hline Igfbp2 & $\begin{array}{l}\text { Insulin-like growth factor } \\
\text { binding protein } 2\end{array}$ & P12843 & $0.200 \pm 0.134$ & & \\
\hline Trh & Thyrotropin-releasing hormone & P01150 & $0.245 \pm 0.013$ & & \\
\hline Ppp1r1a & $\begin{array}{l}\text { Protein phosphatase } 1 \\
\text { regulatory subunit } 1 \mathrm{~A}\end{array}$ & P19103 & & $0.164 \pm 0.032$ & \\
\hline$D c x$ & $\begin{array}{l}\text { Neuronal migration protein } \\
\text { doublecortin }\end{array}$ & Q9ESI7 & & $0.058 \pm 0.036$ & \\
\hline
\end{tabular}

$P$ value indicates two-tailed $P$, unpaired assuming unequal variances.

2001) after normalization to array with median intensity (default) and using background correction for mismatch hybridization. dChip was also used for hierarchical clustering (correlation/centroid mode by cluster tightness) and identification of statistically $(P<0.005)$ enriched gene ontologies.

\section{LC-MS/MS proteomics}

Peptide identification, and quantitative data analysis were performed exactly as described (Martens et al. 2010, Jiang et al. 2013). In brief, using one-dimensional liquid chromatography followed by alternate-scanning tandem mass spectrometry, we compared three biological replicates of 10-week-old $\beta$ cells with four biological replicates of neonatal $\beta$ cells. Each biological replicate represents $0.5-1 \mu \mathrm{g}$ total protein, extracted using Rapigest (Waters Corp., Milford, PA, USA) detergent from an unfractionated $\beta$ cell pool obtained from 15-30 individual rats, resulting in 296 (469) protein identifications in neonatal (10-weekold) $\beta$ cells; a selection of relevant gene ontologies is presented in Table 1. A table listing all identifications is available on request. Relative molar amounts for individual LC-MS/MS runs were calculated as described previously (Silva et al. 2006, Martens et al. 2010); comparison between different cellular isolates was done after normalization toward cyclophilin-A/PPIA (Ppia gene). PPIA was selected as a reference protein as in all neonatal and 10-week-old $\beta$ cell preparations; the PPIA ratio to other housekeeping proteins such as EEF1A1, HSPA8, MDH2, PFN1, TUBB5, and YWHAE showed coefficients of variations $(\mathrm{CV})<35 \%$.

\section{Real-time PCR analysis of rat $\beta$ cells and tissues}

Total RNA was extracted from pancreatic endocrine cells using RNAeasy (Qiagen) minicolumns, according to the manufacturer's protocol. RNA quality was verified by Agilent Bioanalyzer (cutoff RIN $\geq 7$; Santa Clara, CA, USA). Following removal of genomic DNA (TURBO DNAfree, Ambion, Austin, TX, USA) and RT (High-Capacity cDNA Archive Kit, Applied Biosystems), targets were amplified from cDNA template on ABI Prism 7700 Sequence Detector using TaqMan Universal PCR Master

Published by Bioscientifica Ltd. 
Mix and commercially available sequence-specific primers and TaqMan MGB probe (Applied Biosystems, assays' IDs available on request). Also for PCR, Ppia was validated as reference for relative quantification based on its stable expression ratio $(\mathrm{CV}<35 \%)$ toward mRNA level of several other classical reference genes (Ubc, Hprt1, and Psmc5) in all neonatal and adult $\beta$ cell isolates (data not shown), as its absolute mRNA abundance was in the range of $C t$ values of most target mRNAs. $\beta$-actin (Actb) was also invalid as reference for PCR normalization as neonatal $\beta$ cells expressed four times $(P<0.01, n=7)$ more Actb mRNA levels than adult cells, as normalized to Ppia and $U b c$.

\section{Immune stainings}

Non-specific staining was blocked with $10 \%$ donkey serum in PBS followed by incubation overnight at $4{ }^{\circ} \mathrm{C}$ with primary antibodies, $60 \mathrm{~min}$ with secondary antibodies and addition of bisbenzimide (Hoechst 33342, Sigma). Antibody provenance is as follows: anti-insulin (guinea pig, 1:5000, in house, C Van Schravendijk), anti-glucagon (rabbit, 1:2000, in house), anti-delta-like 1 homolog (DLK1; rabbit, raised against intracellular epitope 11021425 bp, 1:1000, provided by J H Nielsen (Carlsson et al. 1997)), and anti-MAFB (rabbit, Bethyl Laboratories, Montgomery, TX, USA; 1:200). Secondary antibodies, raised in donkey, were obtained from Jackson Immunoresearch (Suffolk, UK). Staining was typically done on paraffinembedded tissue after EDTA-antigen retrieval. B6.FVB$\mathrm{Tg}$ (Npy-hrGFP)1Low mice expressing humanized Renilla Green Fluorescent Protein (hrGFP, Stratagene, Agilent) under control of the mouse neuropeptide $\mathrm{Y}(\mathrm{N} p y)$ promoter were generated by B Lowell (Beth Israel Deaconess Med Center, Harvard, USA) and distributed by The Jackson Laboratory (stock number 006417; Bar Harbor, ME, USA). hrGFP fluorescence was recorded on cryosections of freshly isolated pancreas tissue. Images were acquired on Axioplan (Carl Zeiss) microscope using Smartcapture VP Software; digital processing was limited to a $5 \times 5$ soft enhance filter. Correlation of autoradiography with selected protein markers was done using an in-house developed algorithm (G Stangé): pictures were made with a Nikon Eclipse Te2000 inverted fluorescence microscope. TIF files were imported into Attovision for segmentation of the cells on the basis of their DAPI/Insulin/DLK1 intensity. The number of silver granules, representing incorporated ${ }^{3} \mathrm{H}$-tyrosine, was counted within the region of interest of individual cells). All data were exported as flow cytometry standard (FCS) file and further processed with FlowJo (Treestar, Ashland, OR, USA).

\section{Statistical analysis}

Statistical differences were assessed using two-tailed unpaired $T$-test, assuming unequal variances unless otherwise specified.

\section{Results}

\section{Cellular composition and structural characteristics of the isolated neonatal $\beta$ cell fractions}

Endocrine-enriched fractions obtained by density gradient centrifugation of dissociated pancreas from postnatal day 2-3 rats were FACS sorted in cell fractions with high $\left(\mathrm{SSC}^{\mathrm{HIGH}}\right)$ and low (SSC ${ }^{\mathrm{LOW}}$ ) SSC (Fig. 1A). SSC ${ }^{\mathrm{HIGH}}$ cells contained $\pm 90 \%$ cells with endocrine ultrastructure on electron microscopy, composed of $67 \pm 6 \%$ insulin- and $19 \pm 5 \%$ glucagon-expressing cells. The non-granulated SSC $^{\mathrm{LOW}}$ cells were not further studied; they likely represent a mixed population containing few insulin-expressing cells, but predominantly cells expressing mRNA markers of endothelial or mesenchymal cells and pancreatic ductal epithelium (Fig. 1B, $n=15$ ). Around $15 \pm 6 \times 10^{3}$ insulinexpressing cells per neonate were isolated in the $\mathrm{SSC}^{\mathrm{HIGH}}$ window. As $6 \pm 3 \%$ of insulin-positive cells was recovered in the less granulated $\mathrm{SSC}^{\mathrm{LOW}}$ fraction (Fig. 1A), these SSC $^{\mathrm{HIGH}}$ insulin-positive cells are further designated as 'neonatal $\beta$ cells'. They were compared with a reference cell preparation of $88 \pm 3 \%$ insulin purity, FACS purified from 10-week-old rats (Fig. 1C and D). The fraction of all endogenous $\beta$ cells that could be isolated and studied further in vitro was similar in neonates and 10 -week-old rats and amounted to $\pm 10 \%$ of total $\beta$ cell number contained in the whole pancreas (Chintinne et al. 2010).

Electron microscopy indicated a 32\% higher crosssectional surface of 10 -week-old than neonatal $\beta$ cells $(P<0.005$, Supplementary Table 1 , see section on supplementary data given at the end of this article). As their nuclear radius was similar $(r=2.9 \pm 0.2 \mu \mathrm{m}), 10$-week-old $\beta$ cells $\left(1400 \mu \mathrm{m}^{3}\right)$ thus had a 1.6 times higher estimated cytoplasmic volume than neonatal $\beta$ cells $\left(900 \mu \mathrm{m}^{3}\right)$. Adult $(44 \pm 4 \mathrm{pg}$ ins/cell, $n=5)$ and neonatal $(41 \pm 5 \mathrm{pg}$ ins/cell, $n=5) \beta$ cells did not differ in their cellular insulin stores.

\section{Glucose-regulated insulin synthesis and secretion and metabolic redox state of neonatal $\beta$ cells: higher activity at low glucose and lower activity at high glucose}

We compared glucose-inducible protein biosynthesis and secretion by neonatal and 10-week-old $\beta$ cells, during

Published by Bioscientifica Ltd. 
short-term $(1 \mathrm{~h})$ exposures immediately upon cell isolation and during more sustained cultures of $24 \mathrm{~h}$ (Table 2, n=4). Neonatal $\beta$ cells displayed two main differences compared with 10-week-old cells: first, neonatal $\beta$ cells synthesized \pm 2 times less protein $(P<0.005)$ under high glucose $(20 \mathrm{mM})$ stimulation than 10 -week-old cells, and, secondly, they synthesized up to seven times more protein at basal glucose concentrations $(2.5 \mathrm{mM})$. The latter basal hyperactivity appeared to be a stable property of the neonatal $\beta$ cells: i) it was preserved also after 24-h of in vitro exposure (Table 2) and ii) it could also be measured in islets isolated from animals up to 5 weeks old but not older, isolated using the same protocol (Supplementary Figure 1, see section on supplementary data given at the end of this article). Together, both properties account for the markedly lower (5.6-fold, $P<0.005)$ glucose-inducible protein synthesis of neonatal $\beta$ cells, when defined as the increase in molar insulin output per cell by raising glucose concentration from 2.5 to $10 \mathrm{mM}$.

To analyze whether basal hyperactivity was a uniform characteristic of all neonatal $\beta$ cells, protein synthetic activity of individual insulin-positive cells was measured by ${ }^{3} \mathrm{H}$-Tyr autoradiography. A $\beta$ cell was considered to be recruited into a state of activated protein synthesis when it contained $\geq 30{ }^{3} \mathrm{H}$-tyrosine-labeled secretory granules per cell after 30-min exposure to $0-10 \mathrm{mM}$ glucose (Fig. 2A). Neonatal $\beta$ cells contained a higher fraction of cells with

Table 2 Comparison of insulin biosynthesis and secretion of newly synthesized insulin in neonatal and 10-week-old $\beta$ cells. $\beta$ cells were isolated from 1-day-old neonatal and 10-week-old pancreas and compared for their rates of ${ }^{3} \mathrm{H}$-tyrosine incorporation in the protein fraction immunoprecipitated with anti-insulin antibody. Incorporation of the ${ }^{3} \mathrm{H}$-tyrosine label was measured in the intracellular insulin fraction (synthesized intracellular) and in the insulin fraction released into the culture medium (synthesized secreted) over 1- and 24-h incubations at the indicated glucose concentrations. Synthesized total represents sum of newly synthesized intracellular and secreted insulin. Insulin output per $\beta$ cell was corrected for the insulin-positive purity, measured in each individual preparation and averaging $90 \%$ in 10 -week-old and $70 \%$ in neonatal $\beta$ cell preparations. No correction for smaller $\beta$ cell size of neonatal $\beta$ cells was made. Right panel shows a calculation of the insulin synthetic and secretion rates per hour of the 24-h incubations. Data represent mean \pm s.D. of duplicate measurements on $n=4$ independent isolations

\begin{tabular}{|c|c|c|c|c|c|c|c|c|c|c|c|}
\hline \multirow[b]{3}{*}{ Glc $(\mathrm{mM})$} & \multicolumn{3}{|c|}{$\begin{array}{c}\text { 1-h incubation ( } \mathrm{fmol} \text { insulin } / 10^{3} \\
\beta \text { cells per } \mathrm{h} \text { ) }\end{array}$} & \multicolumn{3}{|c|}{$\begin{array}{c}\text { 24-h incubation ( } \mathrm{fmol} \text { insulin } / 10^{3} \\
\beta \text { cells per } 24 \mathrm{~h} \text { ) }\end{array}$} & \multicolumn{5}{|c|}{ Insulin output/h (24 vs $1 \mathrm{~h}$ incubations) } \\
\hline & \multirow{2}{*}{$\begin{array}{l}\text { Neonatal } \beta \\
\text { Mean } \pm \text { s.D. }\end{array}$} & \multirow{2}{*}{$\begin{array}{l}10 \text {-week } \beta \\
\text { Mean } \pm \text { s.D. }\end{array}$} & \multirow[b]{2}{*}{$\begin{array}{l}P_{10-\text { week }} \\
\text { vs neo }\end{array}$} & \multirow{2}{*}{$\begin{array}{l}\text { Neonatal } \beta \\
\text { Mean } \pm \text { s.D. }\end{array}$} & \multirow{2}{*}{$\begin{array}{l}10 \text {-week } \beta \\
\text { Mean } \pm \text { s.D. }\end{array}$} & \multirow[b]{2}{*}{$\begin{array}{c}P_{10-\text { week }} \\
\text { vs neo } \\
\end{array}$} & \multicolumn{2}{|c|}{ Neonatal $\beta$} & \multicolumn{2}{|c|}{ 10-week $\beta$} & \multirow[b]{2}{*}{$\begin{array}{c}P_{10-\text { week }} \\
\text { vs neo }\end{array}$} \\
\hline & & & & & & & $\begin{array}{l}\text { Ratio } \\
24: 1 \mathrm{~h}\end{array}$ & $P_{1}$ vs $24 \mathrm{~h}$ & $\begin{array}{l}\text { Ratio } \\
24: 1 \mathrm{~h}\end{array}$ & $P_{1}$ vs $24 \mathrm{~h}$ & \\
\hline \multicolumn{12}{|c|}{$\begin{array}{l}\text { Synthesized } \\
\text { intracellular }\end{array}$} \\
\hline 2.5 & $44 \pm 8.0$ & $6 \pm 2.4$ & 0.000 & $457 \pm 260$ & $73 \pm 41$ & 0.027 & 0.4 & 0.010 & 0.5 & 0.066 & 0.691 \\
\hline 5 & $55 \pm 15$ & $52 \pm 20$ & 0.809 & $720 \pm 211$ & $356 \pm 196$ & 0.045 & 0.5 & 0.029 & 0.3 & 0.014 & 0.001 \\
\hline 10 & $65 \pm 12$ & $128 \pm 33$ & 0.011 & $1354 \pm 556$ & $1608 \pm 235$ & 0.433 & 0.8 & 0.526 & 0.5 & 0.012 & 0.049 \\
\hline 20 & $64 \pm 11$ & $150 \pm 33$ & 0.003 & $1034 \pm 610$ & $1203 \pm 362$ & 0.651 & 0.6 & 0.174 & 0.4 & 0.002 & 0.099 \\
\hline \multicolumn{12}{|c|}{$\begin{array}{l}\text { Synthesized } \\
\text { secreted }\end{array}$} \\
\hline 2.5 & $0.4 \pm 0.1$ & $0.1 \pm 0.0$ & 0.002 & $26 \pm 11$ & $6 \pm 3.5$ & 0.012 & 3.2 & 0.027 & 2.8 & 0.101 & 0.790 \\
\hline 5 & $0.8 \pm 0.2$ & $0.8 \pm 0.7$ & 0.868 & $70 \pm 39$ & $40 \pm 48$ & 0.367 & 3.9 & 0.042 & 1.6 & 0.466 & 0.160 \\
\hline 10 & $1.4 \pm 0.3$ & $1.3 \pm 0.9$ & 0.887 & $458 \pm 274$ & $865 \pm 295$ & 0.090 & 13 & 0.021 & 40 & 0.001 & 0.106 \\
\hline 20 & $1.9 \pm 0.6$ & $3.2 \pm 1.8$ & 0.221 & $590 \pm 314$ & $1928 \pm 766$ & 0.018 & 12 & 0.014 & 32 & 0.003 & 0.129 \\
\hline \multicolumn{12}{|c|}{$\begin{array}{l}\text { Synthesized } \\
\text { total }\end{array}$} \\
\hline 2.5 & $45 \pm 8.0$ & $6 \pm 2.5$ & 0.000 & $483 \pm 257$ & $79 \pm 44$ & 0.021 & 0.4 & 0.011 & 0.5 & 0.083 & 0.639 \\
\hline 5 & $56 \pm 15$ & $53 \pm 20$ & 0.813 & $790 \pm 203$ & $396 \pm 217$ & 0.038 & 0.6 & 0.037 & 0.3 & 0.017 & 0.003 \\
\hline 10 & $67 \pm 12$ & $130 \pm 33$ & 0.012 & $1812 \pm 419$ & $2473 \pm 296$ & 0.042 & 1.1 & 0.426 & 0.8 & 0.186 & 0.048 \\
\hline 20 & $66 \pm 10$ & $153 \pm 34$ & 0.003 & $1624 \pm 434$ & $3131 \pm 692$ & 0.010 & 1.0 & 0.905 & 0.9 & 0.355 & 0.204 \\
\hline \multicolumn{12}{|c|}{$\begin{array}{l}\text { Fractional } \\
\text { secretion }\end{array}$} \\
\hline 2.5 & $0.9 \pm 0.3$ & $1.3 \pm 0.5$ & 0.170 & $6.4 \pm 3.3$ & $7.3 \pm 2.8$ & 0.707 & & & & & \\
\hline 5 & $1.5 \pm 0.7$ & $1.6 \pm 0.9$ & 0.883 & $9.3 \pm 4.7$ & $10 \pm 10$ & 0.899 & & & & & \\
\hline 10 & $2.2 \pm 0.7$ & $1.0 \pm 0.6$ & 0.037 & $27 \pm 15$ & $35 \pm 9.2$ & 0.397 & & & & & \\
\hline 20 & $3.1 \pm 1.2$ & $2.1 \pm 1.1$ & 0.290 & $39 \pm 20$ & $60 \pm 14$ & 0.133 & & & & & \\
\hline
\end{tabular}

$P$ value were calculated by unpaired Student's $t$-test assuming equal variances $(n=4)$. Insulin outputs are expressed per $10^{3} \beta$ cells following correction for insulin-positive purity but not cell size.

http://jme.endocrinology-journals.org DOI: 10.1530/JME-13-0106
(C) 2014 Society for Endocrinology Printed in Great Britain
Published by Bioscientifica Ltd 
activated protein synthesis, when compared with the 10 -week-old $\beta$ cells (Fig. $2 \mathrm{~B}$ ); even in the absence of glucose, half of neonatal $\beta$ cells showed intense insulin synthetic activity and raising glucose concentration to only $2.5 \mathrm{mM}$ recruited an additional $30 \%$ of cells. To achieve a similar fraction of biosynthetically active cells as neonatal cells at $2.5 \mathrm{mM}, 10$-week-old $\beta$ cells required more than $10 \mathrm{mM}$ glucose. Glucose exerted a dual effect both in neonatal and in 10-week-old $\beta$ cells: apart from the concentration-dependent recruitment of $\beta$ cells into active protein synthesis (Fig. 2A and B) also an additional amplifying effect in the recruited cells was also observed. Although also present in neonatal cells, the latter amplification appeared much stronger (Table 2) in 10 -week-old $\beta$ cells, leading to a three- to fourfold higher maximal synthetic capacity per active $\beta$ cell at 10 weeks. Of note, the basal protein synthetic hyperactivity in neonatal $\beta$ cells was due to increased insulin synthesis with no difference between young/older $\beta$ cells in the amount of non-insulin protein produced (Supplementary Figure 2, see section on supplementary data given at the end of this article).

As insulin production rate in adult $\beta$ cells is stoichiometrically correlated with nutrient oxidation rates (Martens et al. 2006), we examined whether this was also the case in neonatal cells: as an indicator for glucose metabolic rate, we measured acute nutrientinduced $\mathrm{NAD}(\mathrm{P}) \mathrm{H}$ accumulation (Fig. $2 \mathrm{C}$ and $\mathrm{D}$ ) and $\mathrm{FAD} / \mathrm{FMN}$ reduction to $\mathrm{FADH}_{2} / \mathrm{FMNH}_{2}$ (Supplementary Figure $2, n=4)$. In line with their mature secretory competence, 10-week-old $\beta$ cells showed clear nutrientresponsive $\mathrm{NAD}(\mathrm{P}) \mathrm{H}$ fluctuations: $\mathrm{NAD}(\mathrm{P}) \mathrm{H}$ increased sharply by raising glucose from 5 to $10 \mathrm{mM}$, by supplementing $5 \mathrm{mM}$ glucose with equivalent amounts of mitochondrial nutrients D-glyceraldehyde $(1 \mathrm{mM})$ or methylsuccinate $(10 \mathrm{mM})$ or by blocking NADH consumption by complex I inhibitor rotenone. Despite their smaller size, neonatal $\beta$ cells tended to have higher $\mathrm{NAD}(\mathrm{P}) \mathrm{H}$ fluorescence at glucose $\leq 5 \mathrm{mM}$ and this could not be further increased, neither by mitochondrial nutrients nor by rotenone, suggesting that they were already leveled at a plateau phase. FAD/FMN reduction showed similar trend although less discriminating (Supplementary Figure 2). Mannoheptulose blocked $10 \mathrm{mM}$ glucose-induced NAD(P)H (Fig. 2D) and protein synthesis (Supplementary Figure 2C) at both ages, but only in neonatal $\beta$ cells, it partly suppressed insulin synthesis $(P<0.05)$ and $\mathrm{NAD}(\mathrm{P}) \mathrm{H}(P=0.10)$ at low glucose.

Neonatal $\beta$ cells also secreted more insulin at low glucose, although this effect was modest when compared with their lower secretion at high glucose: yet, this basal secretory hyperactivity at glucose $\leq 5 \mathrm{mM}$ was detected both in short-term $(1 \mathrm{~h})$ exposures and in more sustained exposures up to 3 days (Table 2, Fig. 2C, D, E and F, $P<0.05)$. Neonatal $\beta$ cells were less prone to glucoseinduced insulin degranulation in culture (Fig. 2D and E), in part, because they secrete a lower fraction of their insulin content under high glucose stimulation $(P<0.05)$.

\section{Advanced endocrine differentiation of neonatal $\beta$ cells as judged by their mRNA level of conserved $\beta$ cell marker genes}

Lower glucose responsiveness of insulin release by neonatal $\beta$ cells was previously attributed to a generalized immaturity of the specialized $\beta$ cell phenotype detectable by Affymetrix oligonucleotide 230.20 array (Jermendy et al. 2011). We used the same platform to compare the transcriptome of freshly isolated neonatal and 10-weekold rat $\beta$ cells. Considering the $30 \%$ higher insulin purity of 10-week-old $\beta$ cells, a threshold of twofold (lower confidence bound (LCB), $P<0.05, n=3$ ) was selected as minimum for differential expression. Of all assayed transcripts, 2.3\% (Supplementary Table 2, see section on supplementary data given at the end of this article) matched these criteria: 443 transcripts were upregulated in neonatal $\beta$ cells and 270 transcripts were higher in the adult $\beta$ cells. The 270 transcripts upregulated in 10-weekold $\beta$ cells were expected to reflect postnatal maturation of the specialized $\beta$ cell phenotype with anticipated increase in gene expression of key regulators of endocrine function. This was not the case:

First, the genes activated in adult $\beta$ cells showed no statistical enrichment in gene ontologies relating to nutrient-sensing, regulated hormone synthesis or secretion or any other indicator of specialized neuroendocrine function. It showed statistical enrichment $(P<0.001)$ of gene clusters involved in exocrine pancreatic function (peptidases, ribonuclease, triacylglycerol lipase activities, and zymogen granule components; Supplementary Figure 4, see section on supplementary data given at the end of this article), indicating more exocrine contamination. Electron microscopy showed low overall exocrine contamination, but a tendency for more in the 10 -week-old (2\%, Fig. 1B, C and D) than in the neonatal $(1 \%, P=0.45) \beta$ cells.

Secondly, we specifically analyzed mRNA expression of key $\beta$ cell marker genes, using a previously validated panel of 419 probe sets on Affymetrix RG230.20,

Published by Bioscientifica Ltd. 
A
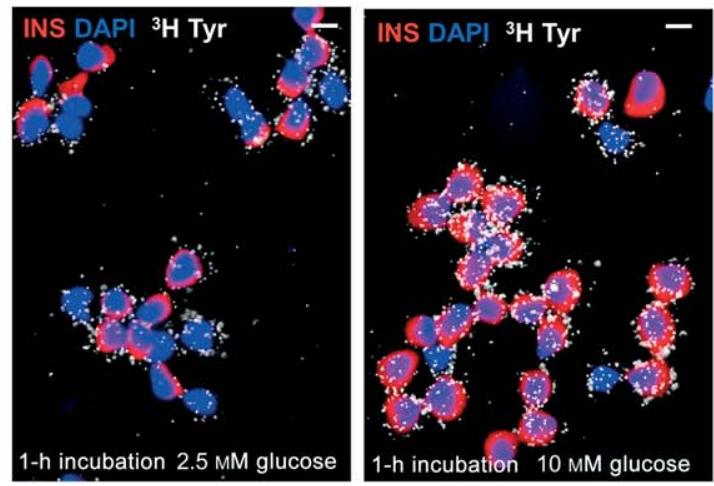

C

1-h incubation

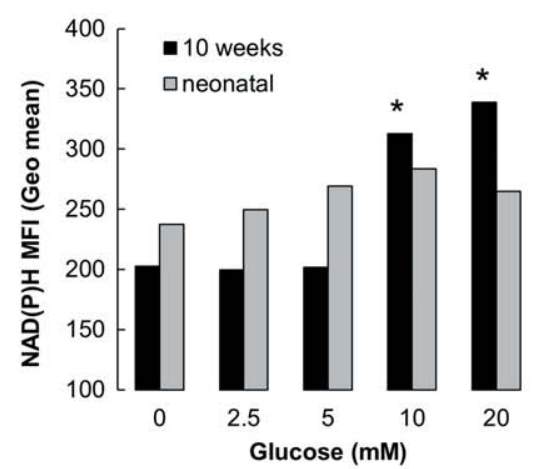

$\mathrm{F}$

E

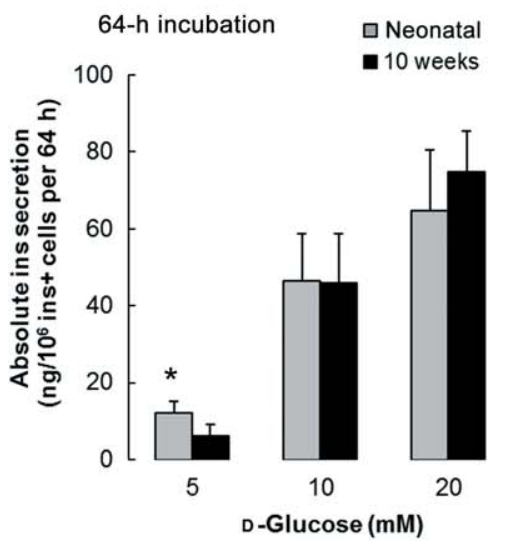

B

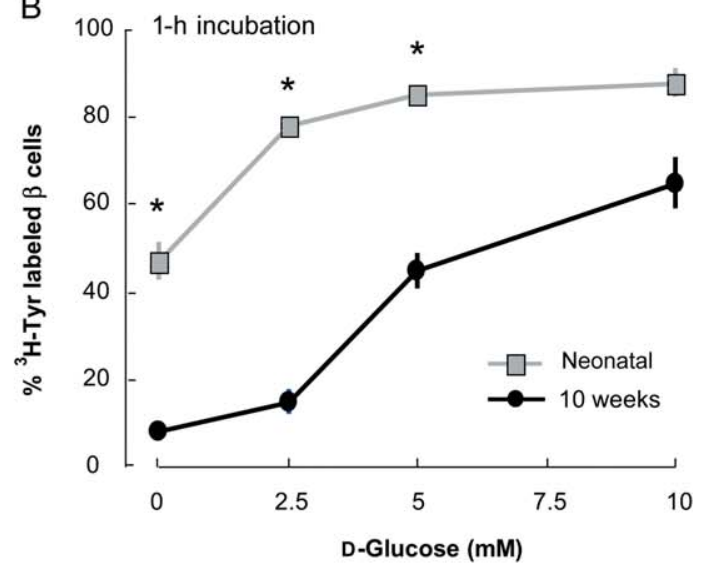

D

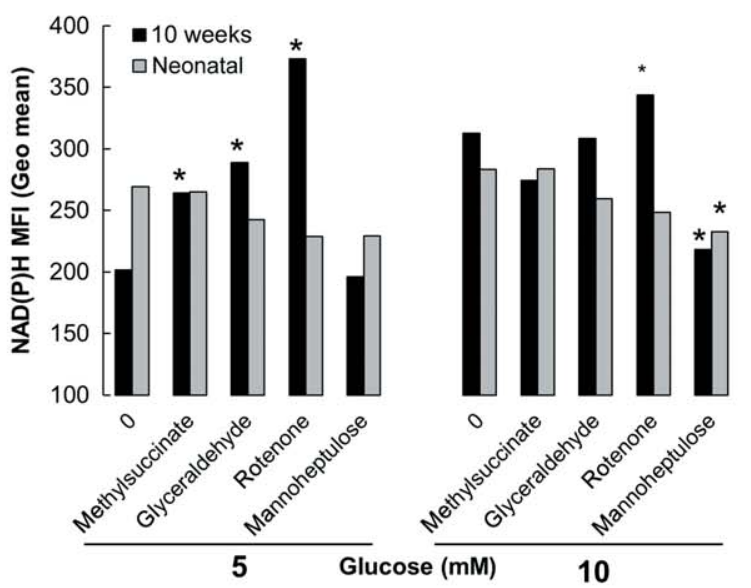

G
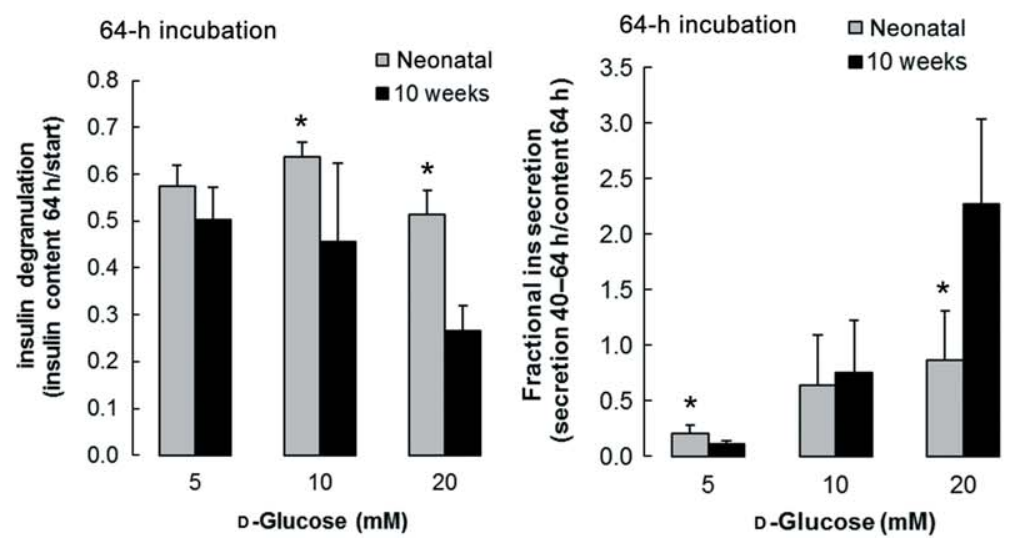

Figure 2

Basal hyperactivity of neonatal $\beta$ cells at level of protein synthesis, cellular $\mathrm{NAD}(\mathrm{P}) \mathrm{H}$, and insulin secretion. (A) Autoradiographic measurement of ${ }^{3} \mathrm{H}$-tyrosine incorporation in secretory vesicles (white dots) in insulinpositive cells (red fluorescence) at 2.5 and $10 \mathrm{mM}$ glucose. Scale bar, $10 \mu \mathrm{m}$. (B) Quantification of insulin-positive cells (mean \pm s.D., $n=5$ independent isolates, $>500$ cells counted/condition) with $>30$ labeled secretory granules after 1 -h labeling in vitro at the indicated glucose concentration in neonatal (gray squares) and 10-week-old (black circles) insulin-positive cells. (C and D) Mean fluorescence intensities of total cellular NAD (P)H as measured by FACS, in freshly isolated, propidium iodide-negative neonatal/10-week-old $\beta$ cells, incubated for $1 \mathrm{~h}$ at the indicated nutrient/inhibitor concentrations. For simultaneously recorded FAD/FMN fluorescence, see Supplementary Figure 2. Bars represent geometric average of $4-5$ isolations. (E, $F$ and $G$ ) The static insulin secretion of aggregated neonatal (gray bars) and 10-week-old (black bars) $\beta$ cells during $64 \mathrm{~h}$ after isolation with medium refreshment every $24 \mathrm{~h}$ : by measuring amount of insulin secreted over $64 \mathrm{~h}(\mathrm{E})$, and measurement of cellular insulin content at start and end of culture $(F)$ and at $40 \mathrm{~h}$ (not shown), fractional excretion can be calculated (G). Bars represent mean \pm s.D., $n=5, * P<0.05$ (unpaired Student's $t$-test) neonatal vs 10 -weekold $\beta$ cells.

Published by Bioscientifica Ltd. 
corresponding to 332 unique genes with a conserved $\beta$ cell-selective expression pattern (Martens et al. 2011). Less than $2 \%$ of these conserved $\beta$ cell marker genes were twofold (LCB) differentially expressed in neonatal and 10 -week-old $\beta$ cells and $<10 \%$ when the threshold was lowered to 1.5-fold (LCB) (Fig. 3A). Gene expression of 22 $\beta$ cell markers was verified by real-time PCR. Only for $N p y$ and St18, the microarray and real-time PCR results were congruent. Relative to their Ppia (and $U b c$, not shown)
mRNA levels, neonatal $\beta$ cells expressed similar levels of Iapp, Dcx, or Gad2 and even markedly higher levels of several other $\beta$ cell marker genes such as Ins 2, Pdx 1, Hadh, Nkx6.1, and Ptprn/Ia- 2 and glucokinase than adult $\beta$ cells (Fig. 3A and $\mathrm{B}, n=4$ ). In view of their different metabolic redox properties, we additionally compared both age groups for differences in mRNA expression of enzymes involved in the metabolism/use of $\mathrm{NAD}(\mathrm{P})+$ and FAD/FMN cofactors (Supplementary Figure 3, see section
A

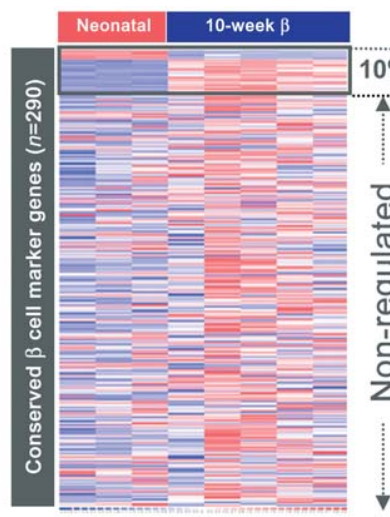

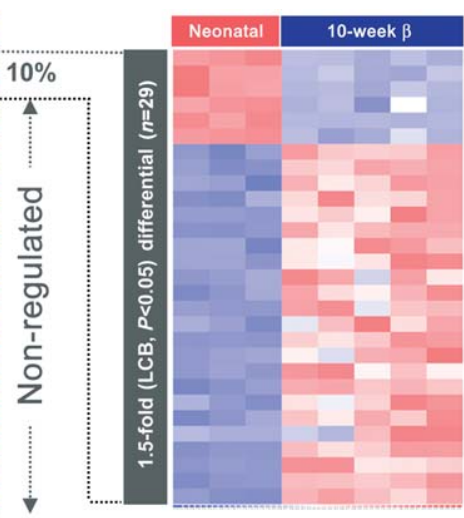
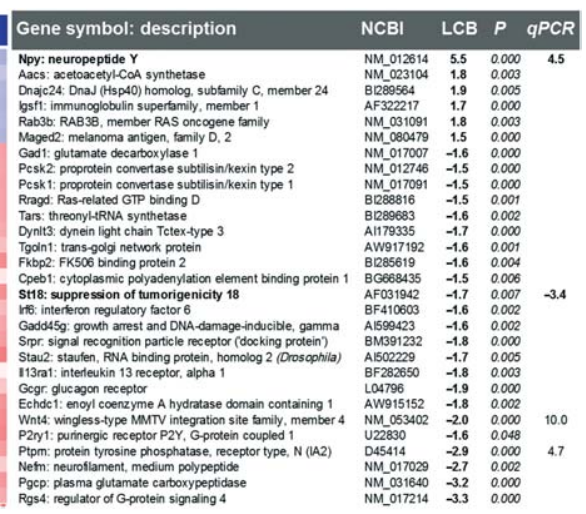

B

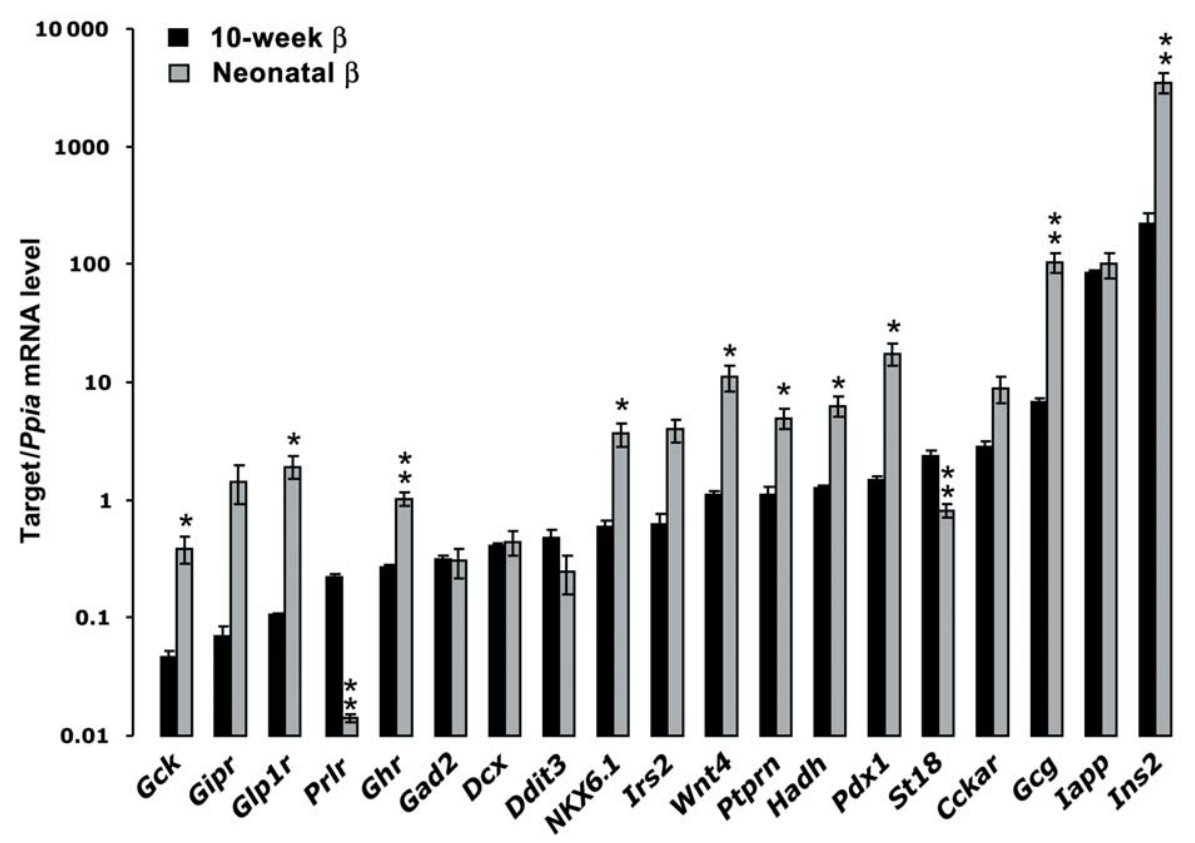

\section{Figure 3}

Neonatal rat $\beta$ cells show advanced differentiation toward the specialized $\beta$ cell phenotype. (A) Compares neonatal and 10-week-old $\beta$ cells on Affymetrix RG230.20 platform for their mRNA expression of a previously validated panel of 332 genes with conserved $\beta$ cell-selective expression (Martens et al. 2011). Even using a relatively loose statistical limit of 1.5-fold difference, only $10 \%$ of these probe sets were differentially expressed, corresponding to 31 non-redundant genes shown on the right of $(A)$ : blue to red indicate low to high mRNA signal on gene chip respectively; genes are indicated by gene symbol, full name, and NCBI accession. Fold change (lower confidence bound (LCB)) of neonate/10-week-old cells is shown with $P$ value $(n=3)$ corrected for multiple comparisons. Plus and minus signs in last column indicate successful or failed confirmations by real-time PCR in (B). (B) mRNA expression levels measured by TaqMan hydrolysis-probe PCR of a panel established and more recently reported (St18, Wnt4, and $D c x) \beta$ cell marker genes. mRNA levels are expressed as percent of Ppia mRNA level in neonatal (black bars) or 10-week-old (gray bars) $\beta$ cells ( $P<0.05, n=3-5$, bars represent mean \pm s.D.). http://jme.endocrinology-journals.org DOI: 10.1530/JME-13-0106
() 2014 Society for Endocrinology Printed in Great Britain 
on supplementary data given at the end of this article). Here again, differences were minimal. One gene stood out: malate dehydrogenase 1 (Mdh1); the cytoplasmic arm of the malate/aspartate NADH shuttle had a sevenfold higher mRNA level in adult $\beta$ cells, in line with previous observations (Tan et al. 2002, Jermendy et al. 2011).

\section{Metabolic and endocrine differentiation as measured by quantitative LC-MS/MS proteomics}

We analyzed unfractionated proteomes of neonatal rat $\beta$ cells $(n=4)$, as was done previously for 10 -week-old rat $\beta$ cells ( $n=3$ ) (Martens et al. 2010), and compared relative molar abundances after normalization to PPIA protein levels. Table 1 highlights protein expression of key enzymes of intermediary nutrient metabolism, various proteins involved in hormone synthesis and secretion, and classical endocrine vesicular constituents. This analysis indicates that acquisition of mature glucose responsiveness associates with a comprehensive twofold upregulation of glycolytic enzymes and the cytoplasmic arm of the malate/aspartate NADH-shuttle, notably MDH1. Neonatal and 10-week-old $\beta$ cells show no marked differences in their expression of various mitochondrial metabolic pathways nor do they differ in their expression of key enzymes involved in protein translation, folding, and vesicle secretion. Quite remarkably, neonatal $\beta$ cells showed two- to threefold higher protein levels of many classical intravesicular proteins, not only of the secretogranin family but also including key hormone-processing enzymes PCSK1 and CPE, often considered as cellular markers of $\beta$ cell maturation.

\section{Candidate markers for residual developmental immaturity}

Four hundred and forty three transcripts showed twofold (LCB, $P<0.05, n=3$ ) higher expression in neonatal than in 10 -week-old $\beta$ cells. These genes were statistically $(P<0.001)$ enriched in gene ontology clusters such as cell cycling, DNA replication, extracellular growth factor signaling, and cell growth (exemplary genes shown in Fig. 4).

Eight genes were successfully confirmed by real-time PCR (Fig. 4, $n=5$ ): these included several novel candidates (Gap43, Nrep, Egln3, and Racgap1) that were strongly (5- to 25 -fold, $P<0.05, n=5$ ) downregulated upon $\beta$ cell maturation, as well as several genes that were previously reported to mark more immature $\beta$ cell stages, and thus serve as positive controls: Dlk1 and Pref1 (Carlsson et al. 1997), Mafb (Nishimura et al. 2006), thyrotropin-releasing hormone (Trh) (Martino et al. 1978, Dolva et al. 1983), and Npy (Myrsen-Axcrona et al. 1997). Npy mRNA was $5 \pm 1$ times $(P<0.05, n=5)$ higher in neonatal $\beta$ cells but could still confidently be detected in 10-week-old $\beta$ cells. By contrast, Mafb and Dlk1 mRNA could not be consistently amplified after 40 PCR cycles in five independent isolates of 10-week-old $\beta$ cells and consequently showed most massive downregulation. In neonatal $\beta$ cells, Dlk1 mRNA showed exceptionally high mRNA abundance, e.g. 1000 and 400 times higher than mRNA level of housekeeping genes Ppia and $U b c$ respectively. Apart from TRH and IGFBP2 proteins - which were confidently detected in $4 / 4$ neonatal $\beta$ cell isolates and in none of the 10 -week-old $\beta$ cell isolates - none of these potential biomarkers were detected by LC-MS/MS.

\section{Neonatal islets contain a mixed population of $\beta$ cells, discerned by their expression of NPY, MAFB, or DLK1}

To correlate functional state of individual cells with their degree of cellular maturation, we set up immune stainings against proteins that showed intense postnatal downregulation of their mRNA in insulin-positive cells. Some candidates - particularly those with also very low abundant mRNA such as GAP43 and EGLN3 - could not be confidently immunodetected in neonatal $\beta$ cells (data not shown); others showed a degree of $\beta$ cell-selectivity but without apparent postnatal downregulation (TRH, NNAT, data not shown).

We were able to confirm a clear postnatal downregulation of three markers in $\beta$ cells, using independently validated in situ methods: NPY, MAFB, and DLK1 (Fig. 5). NPY expression was visualized in transgenic Npy promoter-GFP reporter mice and showed a different pattern, with distinct GFP + and GFP $-\beta$ cell subsets. A similar discerning pattern was observed for DLK1 and MAFB, using well-validated antibodies (Carlsson et al. 1997, Artner et al. 2006). All three markers disclosed heterogeneity in the neonatal $\beta$ cell population: $63 \pm 15$, $54 \pm 20$, and $24 \pm 15 \%$ of neonatal insulin-positive cells expressed Npy-GFP, DLK1, and MAFB respectively $(n=3$ organs, $>5000$ ins + cells counted/organ). In 10-week-old pancreas, NPY protein (not shown) and Npy-GFP could be detected in $6 \pm 3 \%$ of insulin-positive cells. At 10 weeks, the percentage of insulin-expressing cells that also stained for DLK1 (3 $\pm 2 \%)$ or MAFB (1\%) was considered below the limit of quantification of this method.

Published by Bioscientifica Ltd. 


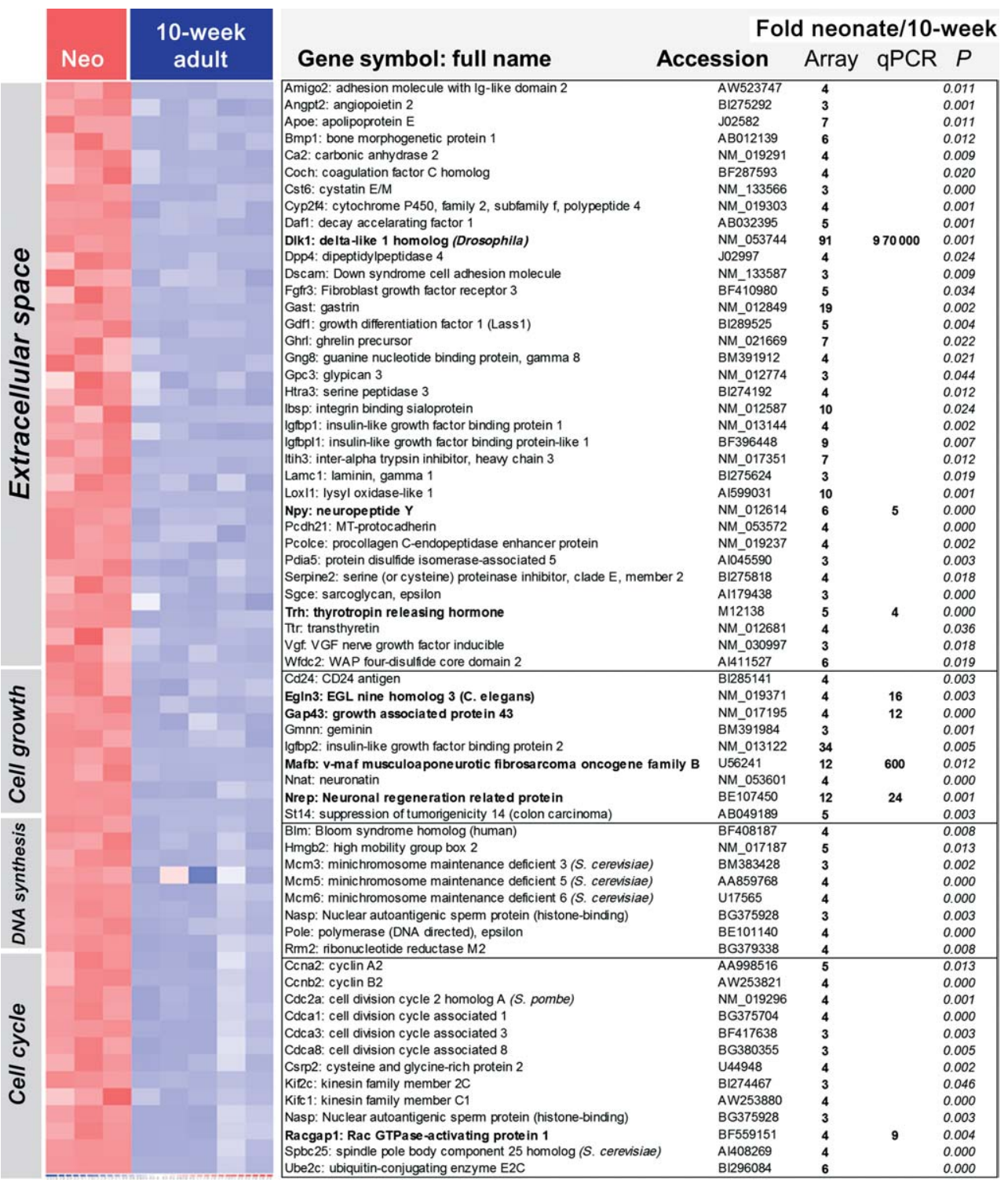

Figure 4

Gene clusters upregulated in neonatal $\beta$ cells. Freshly isolated neonatal (red, $n=3$ ) and 10-week-old rat $\beta$ cells (blue, $n=5$ ) were compared on Affymetrix RG230.20 oligonucleotide array. The set of 443 transcripts was at least twofold $(\mathrm{LCB}, P<0.05)$ upregulated in neonatal $\beta$ cells showed statistical $(P<0.001)$ overrepresentation of gene clusters with role in cell growth, DNA synthesis, cell cycling, and secreted factors. A selection of their most intensely regulated genes is shown from left to right: heat map

\section{Basal protein synthetic activation is not a hallmark of developmental immaturity as marked by DLK1 expression}

In neonates, the fraction of DLK1-expressing $\beta$ cells roughly corresponded to the fraction of $\beta$ cells with basal hyperactivity. As DLK1 was also the most intensely regulated gene, and its apparent abundance allowed confident immunodetection, DLK1 was further used as surrogate biomarker to indicating low (blue) to high (red) mRNA expression levels in 10-week-old adult and neonatal (red, neo) $\beta$ cells, gene symbol and full name, NCBI accession number, fold change in neonatal/10-week-old $\beta$ cells according to the microarray (array, $n=3-5$ ), and for some genes as measured by real-time PCR on independent preparations (qPCR, mean of $n=3$ ), and finally unpaired $P$ value of the microarray results.

investigate whether the protein synthetic hyperactivity at low glucose could be directly correlated with developmental immaturity as marked by intense DLK1 expression. This was studied at the level of individual cells, in short-term (30 min) incubations of single neonatal $\beta$ cell cultures with ${ }^{3} \mathrm{H}$-tyrosine at different glucose concentrations (Fig. 6A and B). Cells were then stained for insulin and DLK1, and after segmentation for

Published by Bioscientifica Ltd. 

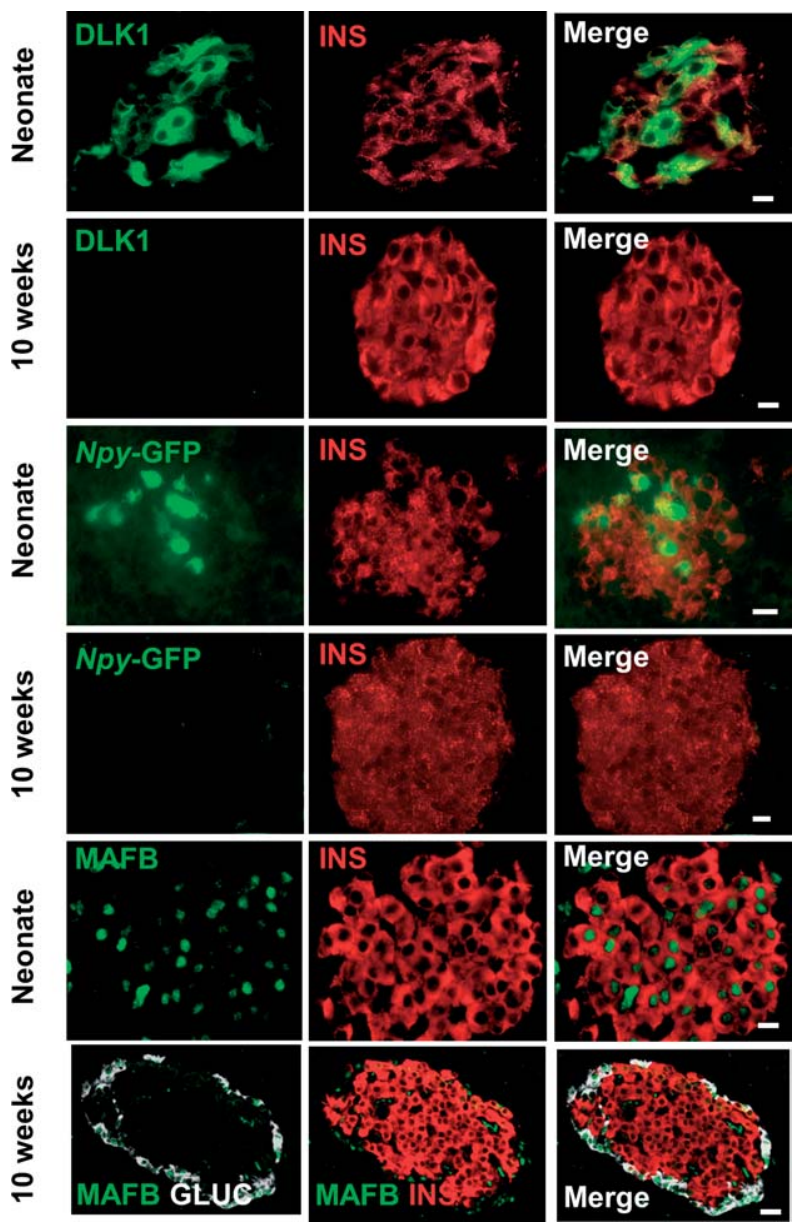

\section{Figure $\mathbf{5}$}

Heterogeneous expression of DLK1, NPY, and MAFB proteins in neonatal $\beta$ cells in vivo and uniform downregulation in adult pancreas. Representative islets from paraffin-embedded neonatal/10-week-old pancreas were double-stained for insulin/DLK1 or triple-stained for insulin/MAFB/ glucagon (GLUC, white). Active Npy gene transcription was visualized by direct GFP fluorescence in fresh cryosections of neonatal and 10-week-old mouse pancreas of Npy promoter-GFP mice. All pictures are representative for at least three animals, with at least three sections per analyzed per animal. White scale bar in merged picture represents $10 \mu \mathrm{m}$.

insulin positivity, $\beta$ cells with high and low DLK1 fluorescence were compared for their number of labeled secretory granules per cell recorded by autoradiography (outlined in Fig. 6A). Glucose concentration dependently recruited more $\beta$ cells into active protein synthesis. Yet, the protein synthetic activity, both basal and at $10 \mathrm{mM}$ glucose, was indistinguishable between DLK1 $1^{\mathrm{HIGH}}$ and DLK1 ${ }^{\text {LOW }} \beta$ cells (Fig. 6B).

\section{Discussion}

It has been known for decades that fetal and neonatal $\beta$ cells, both in rodents and humans, secrete less insulin when stimulated with glucose (Asplund et al. 1969, Grill et al. 1981, Hellerstrom \& Swenne 1991). This glucose unresponsiveness was attributed to an impartial differentiation, in particular relating to specialized features of glucose-sensing $\beta$ cells such as NADH shuttles (Tan et al. 2002), $\mathrm{K}^{+}$ATP channels (Rorsman et al. 1989) or general immaturity with expression of disallowed genes (Aye et al. 2010, Jermendy et al. 2011). Indeed, also our neonatal $\beta$ cell isolates showed a consistent flattening of glucose concentration-response curves at all tested levels: metabolic rate $(\mathrm{NAD}(\mathrm{P}) \mathrm{H})$, insulin synthesis, and insulin secretion. We discerned two distinct features to explain this blunted responsiveness: lower activity at high glucose and higher activity at low glucose. The former is in agreement with previous studies: when a $\beta$ cell matures, its maximal insulin synthetic and secretory capacity under high glucose stimulation increases.

One explanation might be that insulin-productive capacity increases with age due to cellular growth: with their 50\% higher cytoplasmic volume, 10-week-old $\beta$ cells theoretically can accommodate more organelles required for hormone production and release.

Another possible explanation is that neonatal $\beta$ cells show a general lack of endocrine differentiation affecting all core $\beta$ cell functions, e.g. proinsulin translation, folding and processing, vesicle constituents, GTPases involved in vesicle exocytosis, and incretin signaling. Our data argue against this: in fact, when specifically analyzed by oligonucleotide array for their mRNA expression of a large panel of conserved $\beta$ cell marker genes (Martens et al. 2011), neonatal $\beta$ cells appeared almost indiscernible from 10-week-old $\beta$ cells and most statistical differences out to be noise and not confirmed by real-time PCR. Quantitative PCR using hydrolysis probes even suggested up to tenfold higher Ppianormalized mRNA levels of classical $\beta$ cell marker genes: glucokinase, GLP1 receptor, PDX1, insulin 2, IA-2/PTPRN, and HADH were just a few examples. Proteome analysis gave analogous results. LC-MS/MS analysis of unfractionated proteomes is biased toward the more abundant cellular proteins and failed to detect key regulators of $\beta$ cell function/phenotype such as glucokinase, incretin receptors, or transcription factors PDX1 and NKX6.1. On the other hand, alternatescanning LC-MS/MS has the advantage of precise and accurate quantification of relative molar abundances of the identified proteins (Silva et al. 2006, Martens et al. 2010). This showed that neonatal and 10-week-old $\beta$ cells showed no major differences at the level of mitochondrial metabolism (TCA cycle, $\beta$-oxidation, and ATPase) nor at the level of proteins translation, folding,

Published by Bioscientifica Ltd. 
or vesicle dynamics. Again, neonatal $\beta$ cells were found to express higher levels of various classical endocrine markers, such as chromogranin A, the secretogranin family, and insulin-processing enzymes prohormone convertase 1 (PCSK1) and CPE.

The most striking difference was the concerted twofold upregulation of most glycolytic enzymes in 10-week-old $\beta$ cells and the strong upregulation of the cytoplasmic enzymes (MDH1, GOT1) involved in the malate/aspartate NADH shuttle that is crucial for GSIS (Eto et al. 1999). MDH1 was four- and sevenfold upregulated at protein and mRNA level respectively. It also fits with our $\mathrm{NAD}(\mathrm{P}) \mathrm{H}$ measurements: 10-week-old $\beta$ cells showed a sigmoid rise in glucose-induced $\mathrm{NAD}(\mathrm{P}) \mathrm{H}$ in the physiologically relevant glucose range centered around the fasting set point (Martens et al. 2005) and the $K \mathrm{~m}$ of glucokinase. Neonatal $\beta$ cells lacked this glucose-induced $\mathrm{NAD}(\mathrm{P}) \mathrm{H}$ accumulation, and more generally their $\mathrm{NAD}(\mathrm{P}) \mathrm{H}$ appeared already near-maximal at $5 \mathrm{mM}$ glucose, with no additional effect by NADH-generating substrates nor by inhibition of NADH consumption by complex I inhibitor rotenone.
A
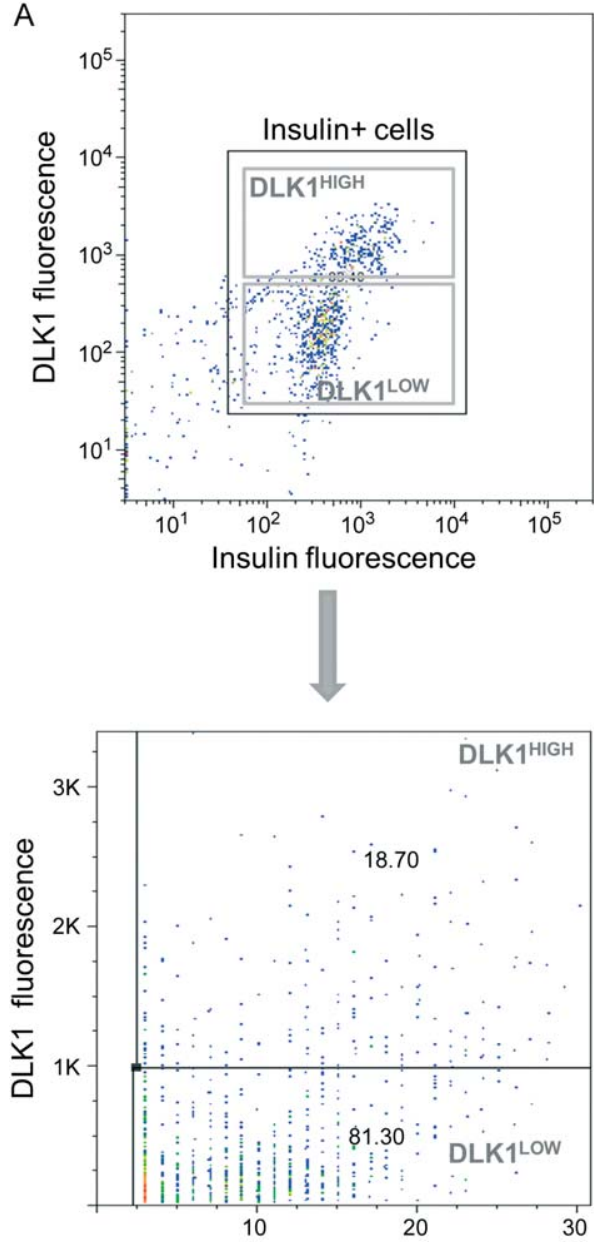

Number of ${ }^{3} \mathrm{H}$-Tyr labeled granules
B

\section{Figure 6}

$\beta$ cells with high or low DLK1 protein expression are indistinguishable in their in vitro proliferation rate and basal protein synthetic hyperactivity. Freshly isolated neonatal $\beta$ cells were single cell-cultured and studied in short-term (30 min) glucose exposures with ${ }^{3} \mathrm{H}$-Tyr for autoradiographic measurement of protein synthetic activity ( $A$ and $B$ ) in individual cells. These events were correlated with DLK1 protein expression status, as outlined in (A): after segmentation of dispersed endocrine cells for insulin expression, they were dichotomously split in a DLK1 ${ }^{\mathrm{HIGH}}$ (gray bars, around Printed in Great Britain
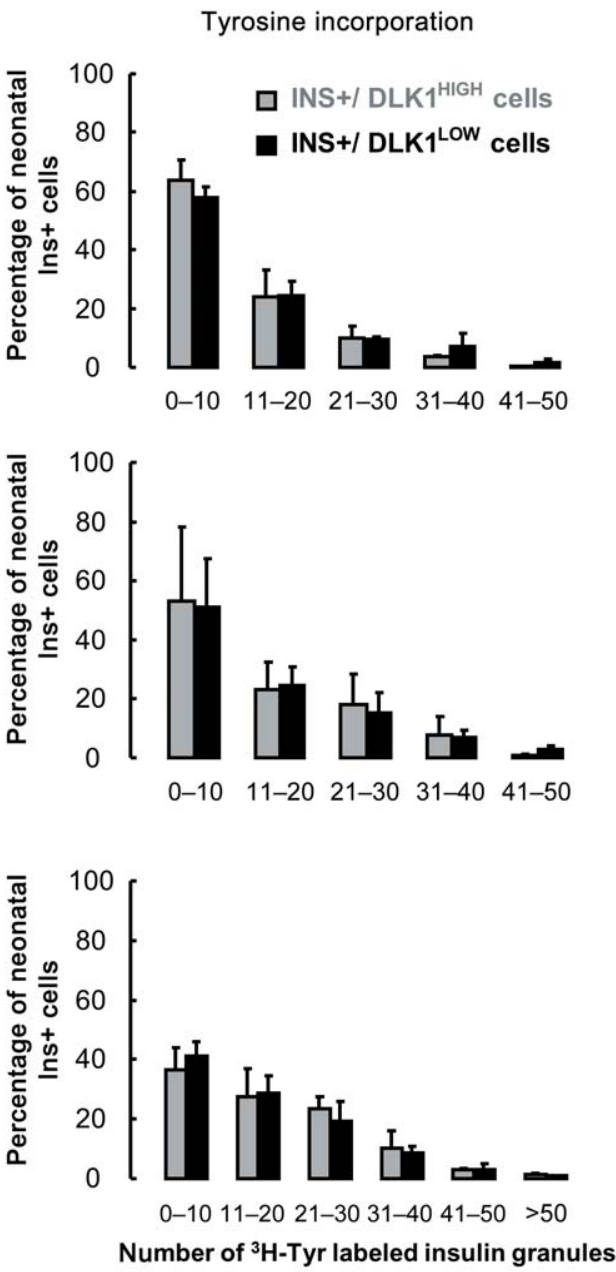

$25 \%$ of all cells at day 1 ) and DLK 1 LOW (black bars, around $75 \%$ cells) subset. After $30-\mathrm{min}^{3} \mathrm{H}$-Tyr chase at the indicated glucose concentration, the number of individual ${ }^{3} \mathrm{H}$-Tyr-labeled secretory granules per cell was counted. Frequency distributions in (B) reflect the fraction of all insulinpositive cells with the indicated number of ${ }^{3} \mathrm{H}$-Tyr-labeled granules per cell. Bars represent mean \pm s.D. of $n=4$ isolates; NS, not statistically different between DLK $1^{\mathrm{HIGH}}$ and DLK1 $1^{\text {LOW }}$ insulin-positive cells.

Published by Bioscientifica Ltd. 
We previously compared the proteomes of 10 -weekold rat $\beta$ cells, dichotomously FACS sorted in a subset with high glucose-induced $\mathrm{NAD}(\mathrm{P}) \mathrm{H}$, and a subset with a more blunted glucose-NAD $(\mathrm{P}) \mathrm{H}$ response (Martens et al. 2010). Interestingly, the exact same pattern was seen as with postnatal acquisition of glucose responsiveness: the highly glucose-responsive subset had a 50\% higher expression of most glycolytic enzymes, with a matched $50 \%$ higher expression of MDH1 and virtually no expression differences in the mitochondrial metabolic enzymes. Higher glycolytic/MDH1 enzyme expression led to higher rates of glucose oxidation and proportionate activation of insulin synthesis and secretion. This emphasis on $\mathrm{MDH} 1 /$ glycolytic $\mathrm{NADH}$ as important determinant for glucose-responsive $\beta$ cell function and its lower activity/expression in functionally immature $\beta$ cells has been observed before, both on isolated fetal rat islets (Tan et al. 2002) as on laser capture-micro (LCM)dissected neonatal rat islets (Jermendy et al. 2011). Methodologically, LCM has the advantage that it avoids the bias on mRNA expression by ER stress imposed during lengthy isolation procedures (Marselli et al. 2009). We confirmed this but also reported that LCM significantly increases bias by contaminating exocrine acinar cells (Martens et al. 2011); evidently, it also precludes direct alignment between gene/protein expression and cellular function, as was done in our study. Nevertheless, the agreement of both approaches with regard to the role of MDH1 and NADH shuttling enforces their complementary value.

The second feature was more surprising and not previously recognized: immature, neonatal $\beta$ cells showed a marked hyperactivity under basal nutrient conditions: at low glucose concentrations, the smaller neonatal $\beta$ cells contained more reduced $\mathrm{NAD}(\mathrm{P}) \mathrm{H}$ and had higher rates of insulin synthesis and secretion. Analysis at the single-cell level using autoradiography indicated that the basal hyperactivity of neonatal $\beta$ cells was explained by a much higher fraction of $\beta$ cells that showed clear biosynthetic activation at glucose concentrations below the $\mathrm{Km}$ of glucokinase. These findings are in line with an overall left-shift of the concentration-response curve of glucose-regulated insulin production in neonatal $\beta$ cells. In fact, this left shift was previously reported by Boschero et al. who observed that neonatal $\beta$ cells had higher flux through glycolysis and pentose-5-phosphate pathway at low glucose concentrations, but lower maximal levels at high glucose concentrations, in agreement with our observed insulin synthetic rates (Boschero et al. 1988, 1990).
This basal hyperactivity was reproducibly observed in $>100$ independent neonatal $\beta$ cell isolations over 10 years in our laboratory, and it persisted for $24 \mathrm{~h}$ or longer after cell isolation and it was unlikely a consequence of differences in isolation technique between neonatal and adult $\beta$ cells: in a separate series of experiments (Supplementary Figure 1), islets were isolated from 5-, 10-, and 40 -week-old rats using the same gradient centrifugation technique as used for neonatal $\beta$ cells, and here again basal hyperactivity was only seen in $\beta$ cells from neonatal, and to a lesser extent 5 -week-old rats.

To investigate whether this basal hyperactivity was a direct reflection of the $\beta$ cells' residual developmental immaturity at the neonatal stage, we needed protein biomarkers to differentiate less and more differentiated $\beta$ cells in situ. Genome-wide mRNA profiling provided several such candidates: in line with their reported higher proliferation rate, we found a three- to fivefold higher mRNA level of gene clusters involved in DNA synthesis, cell cycling, cell growth, or tissue remodeling. Real-time PCR confirmed the activated transcription of $N p y, M a f b$, and Dlk1 genes in neonatal $\beta$ cells, which fits with the previously observed abundant expression of NPY (Myrsen-Axcrona et al. 1997), MAFB (Nishimura et al. 2006, Artner et al. 2007), and DLK1 (Tornehave et al. 1996) proteins in fetal and neonatal $\beta$ cells. Neonatal $\beta$ cell isolates contain threefold more $\alpha$ cells, which can introduce bias in the observed gene expression profiles. In case of NPY, MAFB, and DLK1, in situ immunofluorescence clearly indicated their expression in a subset of neonatal $\beta$ cells and their downregulation at 10 weeks. The most regulated gene/protein was DLK1 (alias Pref-1, giving rise to soluble DLK1 alias fetal antigen-1 (FA1)). Also at the protein level, DLK1 was massively downregulated with age: the neonatal $\beta$ cell population was clearly very heterogeneous, with $\pm 50 \%$ of insulin-positive cells expressing high levels of DLK1 proteins and others no detectable level; when 10 -week-old $\beta$ cells were visualized using the same background fluorescence thresholds, virtually no positive cells could be discerned. This observation does not refute the previously observed residual expression of DLK1 in adult $\beta$ cells (Carlsson et al. 1997, Friedrichsen et al. 2003), or its re-expression under stimulation with growth factors. It does underline the notion that the protein becomes significantly downregulated with advanced maturation, as it does in so many other tissues (Jensen et al. 1994, Tornehave et al. 1996, Floridon et al. 2000, Yevtodiyenko \& Schmidt 2006). Its use as in situ marker to identify the more

Published by Bioscientifica Ltd. 
immature phenotypes in a mixed cell population in vitro thus seems valid. We therefore used DLK1 as biomarker, to verify whether the unique functional feature of the neonatal $\beta$ cell, its basal hyperactivity, was a direct reflection of its (residual) developmental immaturity. The answer was unambiguous: it was not. $\beta$ Cells with abundant DLK1 were equally biosynthetically (hyper)active as those with virtually no DLK1 expression. Of note, DLK1 ${ }^{\mathrm{HIGH}}$ and DLK1 ${ }^{\text {LOW }} \beta$ cells also did not differ in their degree of proliferation (BrdU incorporation) as previously reported (Friedrichsen et al. 2003) and confirmed by us using EdU as label (not shown). This indicates either that DLK1 is not a good biomarker for immaturity or that the observed basal hyperactivity is not an intrinsic property of the immature $\beta$ cell.

The latter option thus suggests that the basal hyperactivity is caused by extrinsic factors: it could thus be a consequence of the nutritional and hormonal extracellular environment and associated metabolic demands imposed on the $\beta$ cell in the neonatal stage. Further research is needed to pin down the responsible triggers, but there are several candidates: neonatal plasma has a different amino acid profile, containing threefold more branched chain amino acids (Martens G, 2011, unpublished observations; $P<0.05$ ), and leucine is a potent secretagogue as well as growth factor for adult and even more for neonatal $\beta$ cells (Boschero et al. 1990). Other possible determinants are the perinatal cortisol surge (Mastorakos \& Ilias 2003), the changes in maternal insulin resistance at the end of pregnancy (Ismail-Beigi et al. 2006), and the high fat feeding by mother milk (Brelje et al. 2008). Our observations not only raise the question that (combination of) factor(s) induce the basal hyperactivity but also whether this functional state might be a key trigger to drive the $\beta$ cell toward proliferation. In this context, a parallel exists with maternal $\beta$ cells in the second trimester of pregnancy that undergo a phenotypic shift, characterized by a leftshift of their glucose responsiveness, insulin synthetic, and secretory hyperactivity, and subsequently also associated with increased $\beta$ cell proliferation (Green \& Taylor 1972, Parsons et al. 1992, Weinhaus et al. 1996). This also fits with the prior observations that activated glucose metabolism not only potentiates the effect of extracellular growth factors (e.g. placental lactogens) on the $\beta$ cell but also acts intrinsically to trigger growth and proliferation (Martens \& Pipeleers 2009, Porat et al. 2011). Further identification of the factors involved is important, as a growing body of evidence indicates that the metabolic conditions that prevail during the last phase of gestation and in the perinatal period are crucial in determining long-term health outcome via epigenetic metabolic programming (Symonds et al. 2009).

In conclusion, this study compares gene expression and glucose-regulated functions of neonatal and 10 -week-old rat $\beta$ cells. It indicates that neonatal rat $\beta$ cells are overall well differentiated as secretorycompetent endocrine cells but require further metabolic fine tuning to become as glucose responsive as the adult $\beta$ cell, both metabolically as in terms of insulin production: this involves on the one hand increasing the glucose-inducible maximal activity - likely associated with maturation of NADH shuttles leading to acquisition of a steeper glucose-NADH response - and on the other hand a down-tuning of basal activity - through mechanisms that still need to be defined. Another clear indication of the residual developmental immaturity of the neonatal rat $\beta$ cells is their expression of many cell cycle- or embryonic development-related proteins such as DLK1 and MAFB. The cardinal functional feature of the neonatal rat $\beta$ cells is their basal insulin synthetic and secretory hyperactivity. Using DLK1 as surrogate marker for immaturity, this hyperactivity does not appear to be a direct manifestation of their immaturity, suggesting that it is triggered by factors in the neonatal homeostatic environment.

\section{Supplementary data}

This is linked to the online version of the paper at http://dx.doi.org/10.1530/ JME-13-0106.

\section{Declaration of interest}

The authors declare that there is no conflict of interest that could be perceived as prejudicing the impartiality of the research reported.

\section{Funding}

This study was supported by research grants from the Research Foundation Flanders (FWO G.0428.09N project grant to $\mathrm{K} \mathrm{H}$ and G A M, FWO project G.0492.12N and Senior Clinical Investigator career support grant to G A M), from the European Foundation for the Study of Diabetes (EFSD/JDRF/Roche Young Investigator Award to G A M), and by the European Union (center grant 241883 to D P under FP7-Health-2009). These funding organizations did not influence data collection and interpretation.

\section{Author contribution statement}

D P participated in study design; G A M, E M, G K, J A, G S, K H, and Z L participated in experimental work and raw data; $G A M$ participated in writing the manuscript; and D P, Z L, K H, J H N, LW G, E M, G S, G K, and J A participated in critical revision of the manuscript.

Published by Bioscientifica Ltd. 


\section{Acknowledgements}

The authors thank J Barthson, B Denys, C Raemdonck, R De Proft, and E De Vos for expert experimental help.

\section{References}

Artner I, Le LJ, Hang Y, Elghazi L, Schisler JC, Henderson E, Sosa-Pineda B \& Stein R 2006 MafB: an activator of the glucagon gene expressed in developing islet $\alpha$ - and $\beta$-cells. Diabetes 55 297-304. (doi:10.2337/ diabetes.55.02.06.db05-0946)

Artner I, Blanchi B, Raum JC, Guo M, Kaneko T, Cordes S, Sieweke M \& Stein R 2007 MafB is required for islet $\beta$ cell maturation. PNAS 104 3853-3858. (doi:10.1073/pnas.0700013104)

Artner I, Hang Y, Mazur M, Yamamoto T, Guo M, Lindner J, Magnuson MA $\&$ Stein R 2010 MafA and MafB regulate genes critical to $\beta$-cells in a unique temporal manner. Diabetes 59 2530-2539. (doi:10.2337/ db10-0190)

Asplund K, Westman S \& Hellerstrom C 1969 Glucose stimulation of insulin secretion from the isolated pancreas of foetal and newborn rats. Diabetologia 5 260-262. (doi:10.1007/BF01212095)

Aye T, Toschi E, Sharma A, Sgroi D \& Bonner-Weir S 2010 Identification of markers for newly formed $\beta$-cells in the perinatal period: a time of recognized $\beta$-cell immaturity. Journal of Histochemistry and Cytochemistry 58 369-376. (doi:10.1369/jhc.2009.954909)

Boschero AC, Tombaccini D \& Atwater I 1988 Effects of glucose on insulin release and $86 \mathrm{Rb}$ permeability in cultured neonatal and adult rat islets. FEBS Letters 236 375-379. (doi:10.1016/0014-5793(88)80059-0)

Boschero AC, Bordin S, Sener A \& Malaisse WJ 1990 D-Glucose and L-leucine metabolism in neonatal and adult cultured rat pancreatic islets. Molecular and Cellular Endocrinology 73 63-71. (doi:10.1016/ 0303-7207(90)90045-A)

Brelje TC, Bhagroo NV, Stout LE \& Sorenson RL 2008 Beneficial effects of lipids and prolactin on insulin secretion and $\beta$-cell proliferation: a role for lipids in the adaptation of islets to pregnancy. Journal of Endocrinology 197 265-276. (doi:10.1677/JOE-07-0657)

Carlsson C, Tornehave D, Lindberg K, Galante P, Billestrup N, Michelsen B, Larsson LI \& Nielsen JH 1997 Growth hormone and prolactin stimulate the expression of rat preadipocyte factor-1/delta-like protein in pancreatic islets: molecular cloning and expression pattern during development and growth of the endocrine pancreas. Endocrinology 138 3940-3948. (doi:10.1210/en.138.9.3940)

Chintinne M, Stange G, Denys B, In 't Veld P, Hellemans K, PipeleersMarichal M, Ling Z \& Pipeleers D 2010 Contribution of postnatally formed small $\beta$ cell aggregates to functional $\beta$ cell mass in adult rat pancreas. Diabetologia 53 2380-2388. (doi:10.1007/s00125-010-1851-4)

Dolva LO, Nielsen JH, Welinder BS \& Hanssen KF 1983 Biosynthesis and release of thyrotropin-releasing hormone immunoreactivity in rat pancreatic islets in organ culture. Effects of age, glucose, and streptozotocin. Journal of Clinical Investigation 72 1867-1873. (doi:10.1172/JCI111149)

Eto K, Tsubamoto Y, Terauchi Y, Sugiyama T, Kishimoto T, Takahashi N, Yamauchi N, Kubota N, Murayama S, Aizawa T et al. 1999 Role of NADH shuttle system in glucose-induced activation of mitochondrial metabolism and insulin secretion. Science 283 981-985. (doi:10.1126/ science.283.5404.981)

Floridon C, Jensen $\mathrm{CH}$, Thorsen P, Nielsen $\mathrm{O}$, Sunde L, Westergaard JG, Thomsen SG \& Teisner B 2000 Does fetal antigen 1 (FA1) identify cells with regenerative, endocrine and neuroendocrine potentials? A study of FA1 in embryonic, fetal, and placental tissue and in maternal circulation Differentiation 66 49-59. (doi:10.1046/j.1432-0436.2000. 066001049.x)

Friedrichsen BN, Carlsson C, Moldrup A, Michelsen B, Jensen CH, Teisner B \& Nielsen JH 2003 Expression, biosynthesis and release of preadipocyte factor-1/delta-like protein/fetal antigen-1 in pancreatic $\beta$-cells: possible physiological implications. Journal of Endocrinology 176 257-266. (doi:10.1677/joe.0.1760257)

Green IC \& Taylor KW 1972 Effects of pregnancy in the rat on the size and insulin secretory response of the islets of Langerhans. Journal of Endocrinology 54 317-325. (doi:10.1677/joe.0.0540317)

Grill V, Lake W \& Freinkel N 1981 Generalized diminution in the response to nutrients as insulin-releasing agents during the early neonatal period in the rat. Diabetes 30 56-63. (doi:10.2337/diab.30.1.56)

Hellerstrom C \& Swenne I 1991 Functional maturation and proliferation of fetal pancreatic $\beta$-cells. Diabetes 40 (Suppl 2) 89-93. (doi:10.2337/ diab.40.2.S89)

Hellman B, Hellerstrom C \& Petersson B 1961 Postnatal growth of the endocrine and exocrine parts of the rat pancrease. Its relationship to the metabolism of DNA. Diabetes $10470-475$.

Hellmann B 1959 The volumetric distribution of the pancreatic islet tissue in young and old rats. Acta Endocrinologica 31 91-106.

Ismail-Beigi F, Catalano PM \& Hanson RW 2006 Metabolic programming: fetal origins of obesity and metabolic syndrome in the adult. American Journal of Physiology. Endocrinology and Metabolism 291 E439-E440. (doi:10.1152/ajpendo.00105.2006)

Jensen CH, Krogh TN, Hojrup P, Clausen PP, Skjodt K, Larsson LI, Enghild JJ \& Teisner B 1994 Protein structure of fetal antigen 1 (FA1). A novel circulating human epidermal-growth-factor-like protein expressed in neuroendocrine tumors and its relation to the gene products of dlk and pG2. European Journal of Biochemistry 225 83-92. (doi:10.1111/ j.1432-1033.1994.00083.x)

Jermendy A, Toschi E, Aye T, Koh A, guayo-Mazzucato C, Sharma A, Weir GC, Sgroi D \& Bonner-Weir S 2011 Rat neonatal $\beta$ cells lack the specialised metabolic phenotype of mature $\beta$ cells. Diabetologia 54 594-604. (doi:10.1007/s00125-010-2036-x)

Jiang L, Brackeva B, Stangel G, Verhaeghen K, Costa O, Couillard-Despres S, Rotheneichner P, Aigner L, Van Schravendijk C, Pipeleers D et al. 2013 LC-MS/MS identification of doublecortin as abundant $\beta$ cell-selective protein discharged by damaged $\beta$ cells in vitro. Journal of Proteomics $\mathbf{8 0}$ 268-280. (doi:10.1016/j.jprot.2012.12.031)

Kaung HL 1994 Growth dynamics of pancreatic islet cell populations during fetal and neonatal development of the rat. Developmental Dynamics 200 163-175. (doi:10.1002/aja.1002000208)

Kiekens R, In 't Veld P, Mahler T, Schuit F, Van De Winkel M \& Pipeleers D 1992 Differences in glucose recognition by individual rat pancreatic B cells are associated with intercellular differences in glucose-induced biosynthetic activity. Journal of Clinical Investigation 89 117-125. (doi:10.1172/JCI115551)

Li C \& Wong WH 2001 Model-based analysis of oligonucleotide arrays: expression index computation and outlier detection. PNAS 98 31-36. (doi:10.1073/pnas.98.1.31)

Marselli L, Sgroi DC, Bonner-Weir S \& Weir GC 2009 Laser capture microdissection of human pancreatic $\beta$-cells and RNA preparation for gene expression profiling. Methods in Molecular Biology 560 87-98. (doi:10.1007/978-1-59745-448-3_8)

Martens GA \& Pipeleers D 2009 Glucose, regulator of survival and phenotype of pancreatic $\beta$ cells. Vitamins and Hormones 80 507-539. (doi:10.1016/S0083-6729(08)00617-1)

Martens GA, Cai Y, Hinke S, Stange G, Van de Casteele M \& Pipeleers D 2005 Glucose suppresses superoxide generation in metabolically responsive pancreatic $\beta$ cells. Journal of Biological Chemistry 280 20389-20396. (doi:10.1074/jbc.M411869200)

Martens GA, Wang Q, Kerckhofs K, Stange G, Ling Z \& Pipeleers D 2006 Metabolic activation of glucose low-responsive $\beta$-cells by glyceraldehyde correlates with their biosynthetic activation in lower glucose concentration range but not at high glucose. Endocrinology 147 5196-5204. (doi:10.1210/en.2006-0580)

Martens GA, Jiang L, Verhaeghen K, Connolly JB, Geromanos SG, Stange G, Van Oudenhove L, Devreese B, Hellemans KH, Ling Z et al. 2010 Protein markers for insulin-producing $\beta$ cells with higher glucose sensitivity. PLOS ONE 5 e14214. (doi:10.1371/journal.pone.0014214) 
Martens GA, Jiang L, Hellemans KH, Stange G, Heimberg H, Nielsen FC, Sand O, van Helden J, Gorus FK \& Pipeleers DG 2011 Clusters of conserved $\beta$ cell marker genes for assessment of $\beta$ cell phenotype. PLOS ONE 6 e24134. (doi:10.1371/journal.pone.0024134)

Martino E, Lernmark A, Seo H, Steiner DF \& Refetoff S 1978 High concentration of thyrotropin-releasing hormone in pancreatic islets. PNAS 75 4265-4267. (doi:10.1073/pnas.75.9.4265)

Mastorakos G \& Ilias I 2003 Maternal and fetal hypothalamic-pituitaryadrenal axes during pregnancy and postpartum. Annals of the New York Academy of Sciences 997 136-149. (doi:10.1196/annals.1290.016)

McEvoy RC 1981 Changes in the volumes of the A-, B-, and D-cell populations in the pancreatic islets during the postnatal development of the rat. Diabetes 30 813-817. (doi:10.2337/diab.30.10.813)

Myrsen-Axcrona U, Ekblad E \& Sundler F 1997 Developmental expression of NPY, PYY and PP in the rat pancreas and their coexistence with islet hormones. Regulatory Peptides 68 165-175. (doi:10.1016/S0167-0115(96)02113-1)

Nishimura W, Kondo T, Salameh T, El Khattabi I, Dodge R, Bonner-Weir S $\&$ Sharma A 2006 A switch from MafB to MafA expression accompanies differentiation to pancreatic $\beta$-cells. Developmental Biology 293 526-539. (doi:10.1016/j.ydbio.2006.02.028)

Parsons JA, Brelje TC \& Sorenson RL 1992 Adaptation of islets of Langerhans to pregnancy: increased islet cell proliferation and insulin secretion correlates with the onset of placental lactogen secretion. Endocrinology 130 1459-1466. (doi:10.1210/en.130.3.1459)

Porat S, Weinberg-Corem N, Tornovsky-Babaey S, Schyr-Ben-Haroush R, Hija A, Stolovich-Rain M, Dadon D, Granot Z, Ben-Hur V, White P et al. 2011 Control of pancreatic $\beta$ cell regeneration by glucose metabolism. Cell Metabolism 13 440-449. (doi:10.1016/j.cmet.2011.02.012)

Rorsman P, Arkhammar P, Bokvist K, Hellerstrom C, Nilsson T, Welsh M, Welsh N \& Berggren PO 1989 Failure of glucose to elicit a normal secretory response in fetal pancreatic $\beta$ cells results from glucose insensitivity of the ATP-regulated $\mathrm{K}^{+}$channels. PNAS $\mathbf{8 6} 4505-4509$. (doi:10.1073/pnas.86.12.4505)

Silva JC, Gorenstein MV, Li GZ, Vissers JP \& Geromanos SJ 2006 Absolute quantification of proteins by LCMSE: a virtue of parallel MS acquisition. Molecular and Cellular Proteomics 5 144-156. (doi:10.1074/mcp. M500230-MCP200)

Symonds ME, Sebert SP, Hyatt MA \& Budge H 2009 Nutritional programming of the metabolic syndrome. Nature Reviews. Endocrinology 5 604-610. (doi:10.1038/nrendo.2009.195)

Tan C, Tuch BE, Tu J \& Brown SA 2002 Role of NADH shuttles in glucose-induced insulin secretion from fetal $\beta$-cells. Diabetes $\mathbf{5 1}$ 2989-2996. (doi:10.2337/diabetes.51.10.2989)

Tornehave D, Jensen CH, Teisner B \& Larsson LI 1996 FA1 immunoreactivity in endocrine tumours and during development of the human fetal pancreas; negative correlation with glucagon expression. Histochemistry and Cell Biology 106 535-542. (doi:10.1007/BF02473268)

Van De Winkel M \& Pipeleers D 1983 Autofluorescence-activated cell sorting of pancreatic islet cells: purification of insulin-containing B-cells according to glucose-induced changes in cellular redox state. Biochemical and Biophysical Research Communications 114 835-842. (doi:10.1016/0006-291X(83)90857-4)

Weinhaus AJ, Stout LE \& Sorenson RL 1996 Glucokinase, hexokinase, glucose transporter 2 , and glucose metabolism in islets during pregnancy and prolactin-treated islets in vitro: mechanisms for long term up-regulation of islets. Endocrinology 137 1640-1649. (doi:10.1210/en.137.5.1640)

Yevtodiyenko A \& Schmidt JV 2006 Dlk1 expression marks developing endothelium and sites of branching morphogenesis in the mouse embryo and placenta. Developmental Dynamics 235 1115-1123. (doi:10.1002/dvdy.20705)

Received in final form 23 August 2013

Accepted 18 September 2013

Accepted Preprint published online 18 September 2013
() 2014 Society for Endocrinology Printed in Great Britain
Published by Bioscientifica Ltd. 